\title{
PERFIL DO USUÁRIO DE TABACO SEM FUMAÇA
}

\section{SUZANA LUZIA COELHO FIGLIOLIA}

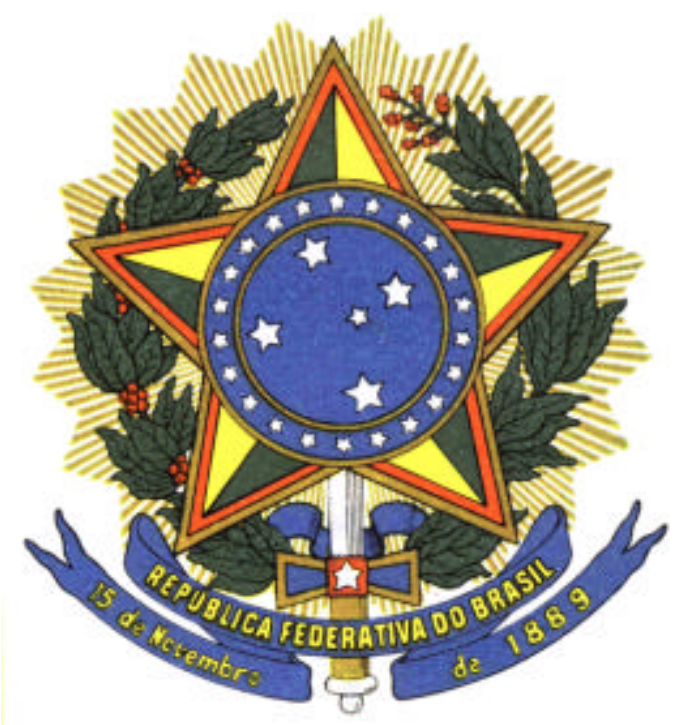

Dissertação apresentada à Faculdade de O dontologia de Bauru, da Universidade de São Paulo, como parte dos requisitos para obtenção do título de Mestre em Odontologia, área de O dontologia em Saúde Coletiva.

Bauru

2001 


\section{PERFIL DO USUÁRIO DE TABACO SEM FUMAÇA}

\section{SUZANA LUZIA COELHO FIGLIOLIA}

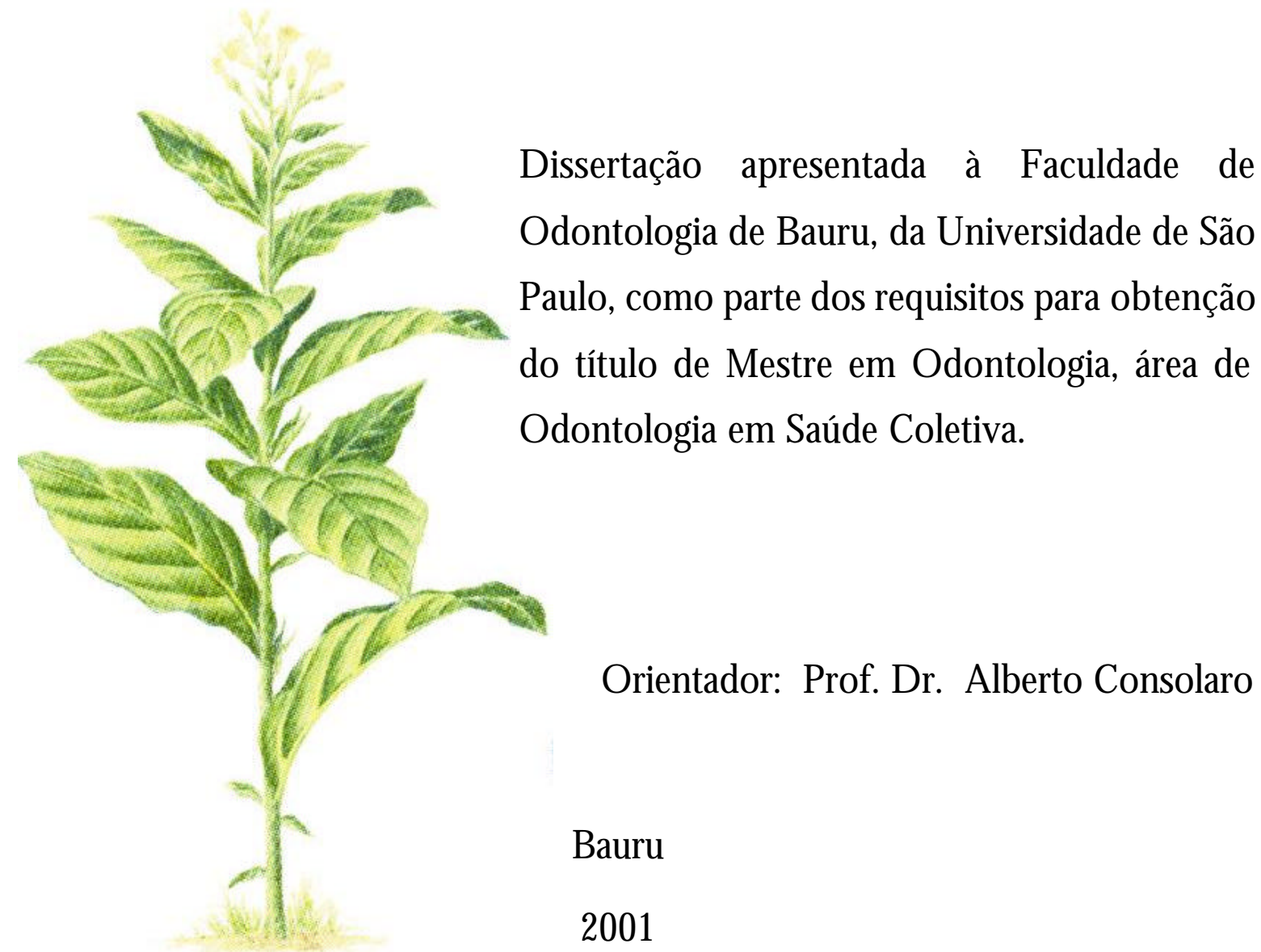




\section{SUZANA LUZIA COELHO FIGLIOLIA}

23 de novembro de 1963 Nascimento

Bauru - SP

Filiação

Luiz José Coelho

Thereza de Jesus Secco Coelho

$1982-1985$

Curso de Graduação em O dontologia pela Faculdade de Odontologia de Bauru USP.

$1999-2001$

Curso de Pós-G raduação em O dontologia em Saúde Coletiva, ao nível de Mestrado, na Faculdade de O dontologia de Bauru USP. 
Desde 1990

Associações
Cirurgiã-dentista - Prefeitura

Municipal de Bauru - SP

CRO - Conselho Regional de O dontologia

do Estado de São Paulo

IAD R - International Association for

D ental Research 
Gostaria de um espaço onde o conhecimento não fosse visto como um "prêmio" que recebemos por nossos "esforços", o conhecimento pertence a cada ser que está no mundo, gostaria de um lugar onde crenças e dogmas cedessem espaço à postura científica, gostaria de um lugar onde o "saber" contido nos Ivros e os conceitos científicos vigentes não fossem aceitos como verdades absolutas; gostaria de um lugar onde cada pessoa tivesse oportunidade de descobrir caminhos próprios de resolver cada desafio que se lhe impõe, onde cada pessoa se sentisse um cidadão do mundo, podendo olhá-lo, transformá-lo e recriá-lo através de sua ação reflexiva; Gostaria de um lugar onde cada um de nós vivesse profundamente 0 prazer, a fruição de se tornar um ser humano cada vez mais inteiro, menos fragmentado, mais inteligente, mais crítico, mais harmonioso, mais consciente e envolvido no profundo e misterioso 


\title{
AGRADEÇO E DEDICO ESTE TRABALHO
}

\author{
A DEUSPAI, \\ Todo Poderoso, pela vida;
}

Aos meus pais LUIZ e THEREZA, e avós OLAVO e HERONDINA, que com muito amor e dedicação nortearam minha formação pessoal;

Ao meu marido, JOSÉ MAURO, pelo incentivo e compreensão, auxiliando-me nos momentos difíceis e ajudandome a alcançar mais este objetivo;

A meus filhos PEDRO e AMANDA, que mesmo sem entender os vários momentos em que estive ausente, souberam me compreender com paciência e amor; 
A minhas irmãs e cunhados

\section{SUZETE eBENTO}

SANDRA EWALTER

pelo constante apoio e incentivo, sempre que precisei;

A minha sogra ELY,

sempre pronta a ajudar quando necessário;

MuitoObrigada 


\section{AGRADECIMENTOS ESPECIAIS}

Ao Professor D outor Albato Consdaro meu orientador, que com seriedade, experiência e profissionalismo conduziu-me no desenvolvimento deste trabalho, mostrando-me que do esforço brota a inspiração e saber viver melhor! 
Ao Professor D outor José Roberto de Magalhães Bastos, sempre nos incentivando, estimulando, transmitindo seus conhecimentos e vivência com muita dedicação.

A Professora D outora Sandra CodhoÁvila deAgriar, que com sabedoria soube me estimular e me ajudar, no desenvolvimento deste trabalho. 


\section{AGRADEÇO AINDA:}

Aos docentes do D epartamento de O dontopediatria, Ortodontia e Saúde Coletiva da Faculdade de O dontologia de Bauru - USP, Prof. Dr. JoséRdbeto de MagalhãesBastos, Prof. D r. VitorianoTnuijoBijella, Prof ${ }^{\mathrm{a}}$ D r ${ }^{\mathrm{a}}$ NilceEmyTomita, Prof. D r. JoséRdbetoPerira Lauris, Prof. ArsenioSalesPeres, Prof. D r. EmetoPildtoGomes Mediros eProf. D r. Eymar Sampaio Lopes pelos ensinamentos transmitidos.

A os docentes da Faculdade de O dontologia de Bauru - USP, responsáveis pela minha formação profissional;

Aos docentes da Disciplina de Patologia da Faculdade de O dontologia de Bauru - USP, Prof. D r. AlbetoConsdaro Prof. Dr. LuísAntôniodeAssisTavera, Prof ${ }^{\mathrm{a}}$ D r ${ }^{\mathrm{a}}$ V anessa Scares Lara e Prof $\stackrel{\text { a }}{\text { D }} \mathrm{r}^{\mathrm{a}}$ DeniseTostes Olivera pela acolhida.

Ao Prof. D r. JoséRdbetoPerira Launis pelo auxiliou sempre que precisei. Ao Prof. ArsenioSales Peres pelo estímulo e amizade.

Ao Prof. D r. LuísAntôniodeAssis Tavera pelo auxílio na busca de locais para realização das entrevistas.

As funcionárias do Departamento de O dontopediatria, Ortodontia e Saúde Coletiva da Faculdade de O dontologia de Bauru - USP, Sílvia, Marta, Hena, Clède, Rosa eCisira pela amizade e agradáveis momentos de convivência.

Aos funcionários da Disciplina de Patologia da Faculdade de O dontologia de Bauru - USP, Bemadkte, Cristina, Fátima eSr. Valdir. 
Aos colegas do curso de Mestrado Prof. Olavo, Renata, Roosevdt, Silaine, Sílvia eTerza

(...)" Como chegar a outro chão, e outros lugares, conhecer novas paisagens, inteirar-se de novos cultivos, se deleitar com outras cores e formas de terra, se espelhar e se moldar, se se recusa a ir??? Para longe ou perto, para próximo ou mui distante, para onde se possa hastear a própria bandeira e dizer: Neste território, eu pisei."

"O medo do Novo" - trecho do livro de Fanny Abramovich"

Aos pós-graduandos da Disciplina de Patologia da Faculdade de O dontologia de Bauru - USP, Jussara, Sandra, Brás, Tânia, Tdma, Simme, Aline, Danid, LaunindbeTarślia pelo companheirismo.

À Raqud Hussnepela ajuda na realização das entrevistas;

À Maria Renata Sales Noguera pela ajuda no material de pesquisa.

Ao Sr. Valdir pela correção ortográfica e gramatical deste trabalho. 
A todos os funcionários da Biblioteca Adarir, César, Cybdle Jane, Maria Hdena, Marica, Theæza, Valéia, Vera pela atenção e orientação que sempre me dedicaram e especialmente a Rita pela paciência.

À Eliana Martins dos Santose Sonia Regina Lqpes do NAPS - Bauru. 
À Direção da Faculdade de O dontologia de Bauru - USP, na pessoa de seu Diretor , Prof. Dr. Aymar Pavaini,

Ao Setor de Pós-G raduação da Faculdade de O dontologia de Bauru USP, presidida pelo Prof Dr. Luíz FemandoPegraro

À Prefeitura Municipal de Bauru, na pessoa do Prefito Nilson Costa, secretária municipal da saúde D $r^{a}$ Eliane Fetter Telles Nunes, D $r^{\underline{a}}$ Sônia Fiochi, $\mathrm{Dr}^{\mathrm{a}}$ Elisabeth Rodigues Pontes, Enfa Margarth Biondo, D $\mathrm{r}^{\mathrm{a}}$ Tema Regina Rodrigues Buem Caldira que possibilitaram-me a realização deste curso,

À Secretaria de Estados da Saúde - DIR X - Bauru na pessoa do Dr. FlávioBadin Marquese suas funcionárias AnaCardina deAndrade Neusa OzaniçMaria Marcanida Togashi e Silvana Pdegina pelo apoio e dedicação com que sempre me receberam,

Ao Centro de Vigilância Epidemiológica (D ivisão de D oenças Crônicas Não-Transmissíveis) - SP na pessoa do Dr. RoddfoBumini pela atenção,

À Agência Nacional de Vigilância Sanitária (D iretoria de Alimentos e Toxicologia) na pessoa do Dr. Mogsés Diskinpelas informações. 


\section{SUMÁRIO}

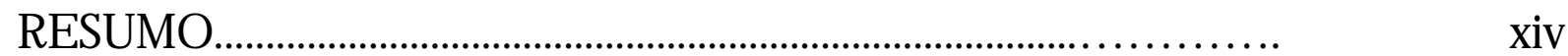

1 INTRODUÇÃO .......................................................................

2 REVISÃO DA LITERATURA......................................................

2.1 TSF: Formas de uso .....................................................................

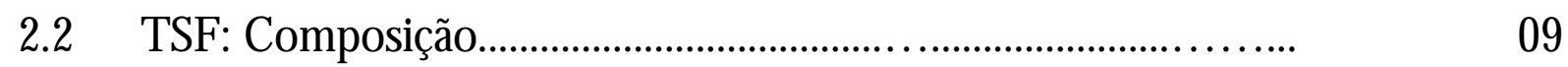

2.3 TSF: Prevalência de acordo com a epidemiologia descritiva em relação as pessoas, características de uso e efeitos deletérios associados ao

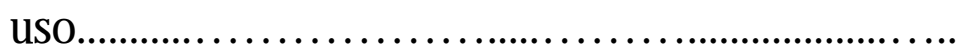

2.4 TSF: Programas de intervenção e papel do cirurgião-dentista..... 32

$2.5 \quad$ TSF: Desempenho dos atletas......................................................

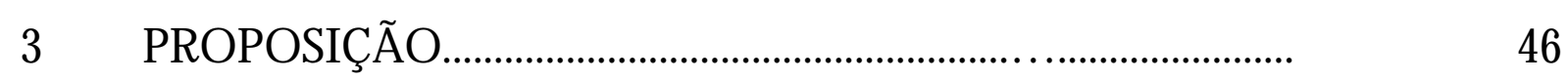

4 MATERIAL E MÉTOD OS.........................................................

$5 \quad$ RESULTAD O S.......................................................................

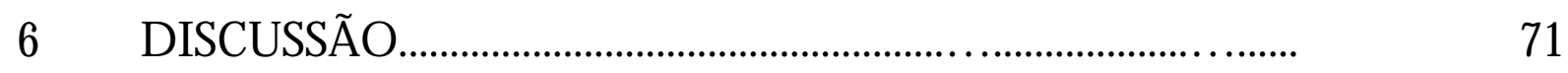

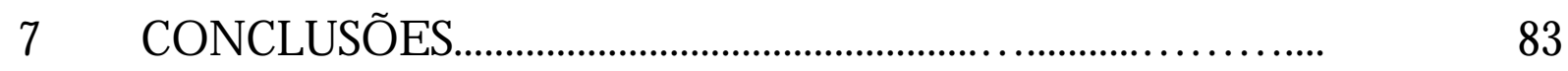

REFERÊNCIAS BIBLIOGRÁFICAS.....................................................

ABSTRACT ............................................................................... 


\section{RESUMO}

Analisando o tabagismo, nota-se o declínio no uso do cigarro pelas campanhas populacionais sobre os malefícios causados pelo vício de fumar. Houve, porém o ressurgimento de um vício milenar presente em rituais e costumes das sociedades indígenas americanas e também praticado por egípcios, persas e chineses desde 0 ano 1000 a.C.: 0 uso do tabaco sem fumaça (TSF). Este vício, nas várias formas como aspirado, aplicado sobre a mucosa e mascado, surgiu como modismo ou substituto do cigarro. As pessoas acreditam ser uma alternativa segura ao cigarro induzidas por um marketing criativo, acondicionando o TSF em latas que lembram as guloseímas e com um visual chamativo, principalmente para os jovens. A metodologia para determinar o perfil do usuário de TSF foi a aplicação de entrevistas auxiliadas pelo preenchimento de um questionário, elaborado especificamente com jovens e adultos freqüentadores de ambientes típicos da cultura "country", como festas de rodeio, aulas de treinamentos de hipismo e campeonatos da modalidade na região de Bauru. 0 usuário de TSF na região de Bauru, Estado de São Paulo, caracterizou-se por ser: adolescente do gênero masculino, da raça branca, de escolaridade média, pertencente à classe média, de conhecimento dos pais a prática do vício e freqüentador de ambientes "country".

Os resultados possibilitam ainda concluir que há necessidade de providências no âmbito da saúde coletiva e da comunidade odontológica para tomada de posição e consciência da sociedade sobre os malefícios do vício do uso do TSF pois representa um grave e insidioso problema social. 
1 INTRODUÇÃO 


\section{INTRODUÇÃO}

O uso do tabaco* faz parte de uma cultura milenar iniciada no continente africano e asiático desde 0 ano 1000 a.C. sendo consumido pelos egípcios, persas e chineses. As sociedades indígenas da América Central utilizavam-no em rituais mágicos e religiosos com objetivo de purificar, contemplar, proteger e fortalecer os guerreiros e também para usufruir de seus poderes medicinais ${ }^{47,57,67}$.

A planta do tabaco ou Nictiamatabaam(figura na folha de rosto) chegou ao Brasil com a migração dos tupi-guaranis. Em seus rituais, queimavam folhas de tabaco e ficavam ao redor inalando sua fumaça, usufruindo a sensação de prazer e alívio em decorrência do efeito farmacológico de algumas substâncias presentes como a nicotina ${ }^{58}$.

Com a chegada dos portugueses ao Brasil, Jean Nicot, diplomata francês advindo de Portugal, teve uma úlcera cicatrizada na perna com o uso do tabaco. A proveitando, enviou este produto para a rainha da França, Catarina de Médici, com o intuito de curá-la de suas enxaquecas, introduzindo o tabaco na Europa ${ }^{57}$.

No início, o tabaco foi usado para curar, mas no século XVII com a utilização do cachimbo, o seu uso recreacional difundiu-se rapidamente para Ásia e África. Já no século seguinte, o tabaco passou a ser usado em forma de pó ou rapé. Sua inalação provoca sucessivos espirros, considerados a sensação da época,

\footnotetext{
* tabaco: derivado do taino, idioma indígena, significando instrumento com que os índios fumavam.
} 
estabelecendo-se como moda nas altas rodas sociais. 0 rapé era guardado em caixinhas de ouro ou prata pelos mais ricos e em pequenos depósitos, nos anéis ${ }^{52}$.

Outra maneira de preparação do tabaco consiste em formar rolos com as folhas de tabaco curtidas, dando origem ao "fumo de corda", mastigado e depois cuspido. Também pode ser ainda picado e enrolado em palha de milho, fumando-se de forma semelhante aos cigarros atuais ${ }^{52}$.

No século X IX , o charuto foi símbolo de ostentação e passou a ser usado rotineira e inicialmente pela Espanha, disseminando-se pela Europa, Estados Unidos da América (EUA) e outros continentes ${ }^{58}$.

O tabaco passou a fazer parte da economia brasileira e suas folhas comercializadas sob a forma de fumo para cachimbo, rapé, tabaco para mascar e charuto, iniciando sua industrialização sob a forma de cigarro no final do século XIX. As folhas de tabaco assumiram um papel de fundamental importância na economia do Brasil a ponto de serem incorporadas ao Brasão da República ${ }^{57}$, como está representado na capa.

Nas últimas décadas, a utilização do tabaco ressurgiu nas suas formas iniciais: rapé e tabaco de mascar. Agora de maneira requintada, industrializada e apoiada em marketing criativo, procura mudar o perfil do usuário de zona rural e média idade ou mais, para adolescentes e adultos jovens de centros urbanos, freqüentadores de ambientes típicos de cultura "country" e praticantes de certas modalidades esportivas.

Na literatura nacional, não existem dados referentes ao uso do TSF e ao perfil de usuários e que pudéssemos resgatar. Não encontrou-se normas ou regras para a sua regulamentação ou legislação quanto ao seu uso, sendo adquiridos nas várias formas e diversos sabores em tabacarias e estabelecimentos especializados em artigos "country". 
Alguns questionamentos surgiram:

- Qual o potencial carcinogênico do TSF?

- Qual o nível de consumo no mercado brasileiro? Há marcas nacionais?

- Qual o tipo de consumidor, quanto à idade, à raça e ao nível sócio econômico?

- Q uando e como o consumidor brasileiro faz uso do TSF?

- Quando se inicia seu uso e quem ou o que o estimula?

- O cirurgião-dentista conhece este problema e suas conseqüências bucais?

- 0 cirurgião-dentista está preparado para diagnosticar as lesões provocadas e identificar o usuário do TSF?

Para contribuir com o esclarecimento social e difundir o conhecimento do problema no meio odontológico nacional, trabalhos epidemiológicos iniciais podem fundamentar uma conscientização mais ampla quanto aos malefícios do vício do TSF nos tecidos bucais. 
2 REVISÃO DA LITERATURA 


\section{REVISÃO DA LITERATURA}

Este capítulo foi dividido em tópicos para melhor compreensão do vício e do produto relacionado ao tabaco sem fumaça em suas variáveis e implicações.

\subsection{FORMAS DE USO DO TABACO SEM FUMAÇA OU TSF}

0 uso do tabaco na forma sem fumaça, mascando-se suas folhas ou aspirando-o na forma de pó, está registrado há centenas de anos $\mathrm{s}^{21,47}$.

Em 1990, SPEER ${ }^{72}$ encontrou vários tipos de TSF no mercado:

1) para mascar, caracterizando-se pelo tabaco seco, ralado e adoçado com alcaçuz ou mel e vendido como "plug" ou tijolos, "twist" ou trançado/ corda, "finecutt" ou finamente picado e ainda "scrap" ou em pedaços;

2) para simplesmente colocar na mucosa ou "snuff" na forma de pó a ser misturado com especiarias, adoçantes e com aroma de menta ou floral;

3) para cheirar, também conhecido como rapé, na qual o tabaco tratado é finamente moído resultando em pó a ser aspirado. 
Entre os produtos de TSF, o tabaco de mascar e o "snuff" são as duas formas mais consumidas nos EUA, consistindo o tabaco de mascar em folhas de tabaco moídas grosseiramente e adoçadas, soltas ou na forma de "plugs" ou "twists", que podem ser mastigadas ou deixadas entre a bochecha e a gengiva. 0 "snuff" úmido é acondicionado em latas, sem ser espremido, sendo esta a forma mais popular e tipicamente encontrada, podendo também ser encontrado em pequenos sachês. 0 usuário coloca uma pequena porção entre a bochecha e a gengiva e a deixa por variáveis períodos de tempo. Nos EUA, a produção de TSF aumentou quase 40\% entre 1965 e 1980, atualmente permanece estável, com exceção da produção do rapé úmido que tem aumentado quase $40 \%$ desde $1980^{21,38,41}$.

Na Ásia, o tabaco pode ser usado misturado ao "betel quid" ("pan"), pois mascar o "pan" faz parte da cultura e varia de acordo com os costumes locais e preferências individuais, como relataram SUMMERS; WILLIAMS; CURZON ${ }^{77}$ em 1994. Os componentes do "pan", em sua maioria são constantes e consiste da folha de betel, noz de areca cortada em fatias, cal preparado de pedra calcária ou de coral e "catechu" (um extrato resinoso da árvore de acácia com alto conteúdo de tanino). A esta mistura pode adicionar-se o tabaco ou ainda outros ingredientes.

As folhas de betel são untadas com cal e "catechu" e dobradas como um funil e adicionados os outros ingredientes; depois de pronto coloca-se na boca, usualmente na bochecha para ser mascado ou chupado por um período de tempo ${ }^{73}$.

De acordo com ANDERSON; BJÖ RNBERG ; CURVALL², em 1994, 0 vício bucal de usar rapé úmido revela-se bastante comum na Suécia em duas formas: 0 rapé solto e o rapé empacotado em pequenas porções ou pacotinhos. Estes são fabricados com tabaco moído aplicando-se um tratamento com calor. A produção dessas formas de rapé úmido pela Suécia domina quase 100\% do 
mercado mundial de TSF, a ponto da venda anual do tabaco de mascar na Suécia parece pequena quando comparada ao rapé úmido (13 toneladas x 5000 toneladas).

Os produtos do tabaco podem ser fumados, mascados ou inalados. Nos EUA prevalecem dois tipos de TSF: o rapé e o tabaco de mascar. Em ambas as formas do rapé, úmido ou seco, aplica-se o "dipped" ou passar o dedo sobre o pó e em seguida esfregá-lo na mucosa bucal, entre o lábio inferior ou bochecha e a gengiva quando então se mistura à saliva. No rapé, a folha de tabaco é finamente moída ou triturada e vendido em pequenas latas de alumínio ou sachês, como os de chás. $\mathrm{Na}$ forma de mascar, o usuário coloca uma porção de tabaco em forma de "plugs" onde a folha de tabaco é cortada de modo grosseiro ou "twist" uma forma em que a folha de tabaco é enrolada semelhante a uma trança e aos pedaços colocado na boca para sua mastigação $0^{20,32,64,82}$.

GREEN ${ }^{31}$, no ano de 1995, relata que essas duas formas de TSF, rapé e de mascar, diferem basicamente na forma de empacotamento, pois o tabaco de mascar é vendido em sacos com revestimento de alumínio e o "snuff" em latas.

Para avaliar a prevalência de todas as formas de uso do tabaco (cigarro, charuto, cachimbo e TSF) nos EUA, em 2000, RIGOTTI; LEE; WECHSLER ${ }^{63}$ enviaram questionários para 23751 estudantes de 119 escolas de ensino universitário. As respostas eram anônimas e 60\% dos questionários retornaram, confirmando que o uso do tabaco em todas suas formas é comum entre estudantes, não limitando-se ao uso do cigarro. As diferenças encontradas foram quanto às características dos usuários de acordo com a forma usada; a porcentagem para 0 uso do cigarro é semelhante para ambos os gêneros ao contrário do charuto, cachimbo e TSF que prevalecem no gênero masculino. Na raça branca prevalece 0 tabagismo, com exceção do charuto cujo uso é similar entre brancos e negros, 
concluindo-se sobre a necessidade de esforços nacionais para reduzir o vício de todas as formas de tabaco.

O uso do TSF é praticado de inúmeras formas em diversas partes do mundo: na Inglaterra, na forma de pó e aspirado ${ }^{22}$, nos países da Escandinávia, EUA e Suécia, prevalece o uso do "snuff" bucal ${ }^{2,64,82}$, no Sudão, o fumo de mascar conhecido como "toombak", constituído por uma mistura de tabaco com bicarbonato de sódio ${ }^{39}$, na Ásia consome-se o betel quid associado ou não ao $\operatorname{tabaco}^{81}$.

\subsection{TSF E SUA COMPOSIÇÃO}

Os ingredientes na preparação do TSF são bastante variáveis de acordo com a cultura, costumes e preferências ${ }^{5,18,39,77}$ :

- folha ou fruto de betel

- noz de areca

- cal em pó ou pasta

- catechu

- anis

- cardamomo

- zarda

- bicarbonato de sódio

- folha de tabaco.

Em 1980, em estudo analisando o conteúdo de açúcar e flúor em marcas populares de tabaco de mascar e "snuff", GOING et al. ${ }^{30}$ encontraram alto 
conteúdo de açúcar: 30 a 40\% do peso em três marcas de folhas de tabaco para mascar (Red Man, Beech-Nut e Big Red). Em uma das marcas do tabaco para mascar (D ays-O-Work), a média de açúcar foi em torno de 26\% do peso; em contraste encontraram menos que $2 \%$ de açúcar do peso em duas marcas populares de "snuff" (Skoal e Copenhagen) nas formas de glicose, frutose, sacarose, maltose e isomaltose.

Em 1995 BOWLES et al. ${ }^{9}$ analisaram 16 diferentes marcas de charuto, oito marcas de rapé e quatro de tabaco de mascar, para verificar o conteúdo de partículas abrasivas nesses produtos. Nas folhas de tabaco, charutos, rapé e tabaco de mascar foi encontrada uma concentração média de 0,5\% do peso seco do tabaco constituído por partículas minerais insolúveis, na maioria sílica ou dióxido de silício, provavelmente presentes nas folhas desde os campos de plantação ou pelo metabolismo da planta ao retirar essa matéria do solo e levá-lo até a folha. Estas partículas não poderiam ser removidas por nenhum processo sem destruição do tabaco e contribuem para o desgaste dentário com o uso crônico.

Na cartilha de prevenção contra drogas e AID S do Ministério da Saúde, BUCHER $^{11}$ em 1995 cita o tabaco como uma droga legal, lícita, estimando que $50 \%$ dos homens e 33\% das mulheres brasileiras fumam, classificando a nicotina contida no tabaco como uma droga estimuladora que causa inúmeros malefícios cardiovasculares e respiratórios, levando a dependência física e psíquica ${ }^{69}$, mas tem seu uso protegido pelo Estado.

Em relato de GREEN ${ }^{31}$, em 1995, já foram isolados 2.500 diferentes compostos químicos no rapé e tabaco de mascar, entre eles, os mais comuns são: açúcar, areia, brita, sódio, tabaco, nicotina e quatro grupos de carcinógenos: 1. compostos metálicos: arsênio, cádmio e níquel; 2. compostos radioativos: chumbo 
e polônio; 3. hidrocarbonetos polinucleares: alcatrão e 4. nitrosaminas: os mais potentes e perigosos carcinógenos.

CHRISTEN; CHRISTEN ${ }^{20}$, em 1996, citaram várias formas do TSF, naturais ou com sabores, adoçadas com açúcar ou mel, revelando um conteúdo de glicose ou sacarose entre 5 a $15 \%$ do peso.

Em torno de 30 carcinógenos, são identificados no TSF, sendo as $\mathrm{N}$ nitrosaminas tabaco-específicas, ou TSNA, as de maior prevalência e atividade carcinogênica $^{34,38,86}$; são formadas exclusivamente da nicotina, durante o processo de fermentação e envelhecimento do tabaco. As TSNA são carcinógenos orgãoespecíficos e independente da via de aplicação induzem tumores específicos ${ }^{38}$. Os níveis de nicotina e TSNA são os mesmos no "snuff" em sachês e no de latinhas, enquanto no tabaco de mascar o conteúdo de nicotina é duas vezes maior por grama de produto e a quantidade de nitrosaminas menor que no "snuff". $\mathrm{O} \mathrm{pH}$ dos produtos do "snuff" é alcalino $(7,9$ - 8,6) e cerca de 0,5 maior nos de latas do que nos de sachês; o pH do tabaco de mascar é similar ao do tabaco puro $(4,9)$, pois não ocorre mudanças durante o processo ${ }^{1}$.

Com a finalidade de analisar o conteúdo de nicotina nos produtos de TSF, TILASHALSKI; RODU; MAYFIELD ${ }^{78}$, em 1994, selecionaram 11 marcas de TSF: seis de rapé úmido, três de folhas para mascar e duas marcas de mascar do tipo "plug". Os resultados mostraram que o conteúdo de nicotina entre os produtos de tabaco pode ser muito variável: em quatro marcas de rapé úmido, a concentração encontrada esteve em torno de 3\%, os "plugs" apresentaram de 1,6 a $2 \%$ e as folhas para mascar, menos que 1\%. Essas variações podem ser resultado das características do tabaco pela habilidade de absorver aditivos, bem como pela influência da umidade. As folhas de tabaco contêm adoçantes como açúcar e 
melado em maior quantidade que o rapé úmido, em torno de quinze vezes mais. Essas diferenças na concentração, na exposição, nas preferências e uso, podem ser importantes no estudo dos efeitos adversos, devendo esse tipo de informação no futuro estar disponível para pesquisadores e consumidores de TSF em suas embalagens.

O TSF contém mais nicotina que o cigarro; uma porção do tabaco de mascar contém 133mg, de rapé úmido 14,5mg e em um cigarro 8,4mg, conforme BENOWITZ $^{7}$ em relato de 1997. Enfatizaram que há ocorrência de uma considerável variação na quantidade de nicotina absorvida do TSF entre os usuários, mesmo quando eles usam a mesma quantidade em suas bocas.

\subsection{EPIDEMIOLOGIA DESCRITIVA EM RELAÇÃO AS PESSOAS, CARACTERÍSTICAS DE USO E EFEITOS DELETÉRIOS}

Nos EUA, atualmente, o perfil do usuário de TSF compõe-se de préadolescentes, adolescentes e adultos jovens, principalmente do gênero masculino, da raça branca, alunos de $2^{\underline{0}}$ grau, da classe média e alta ${ }^{79,80}$. O utros usuários são moradores de área rural, pessoas relacionadas ao meio "country" e fumantes tentando substituir o vício do cigarro por acreditar que o TSF seja menos prejudicial à saúde.

Preocupados com as alterações que ocorrem nos tecidos bucais associadas ao uso do TSF, em 1983, GREER; POULSON ${ }^{33}$ identificaram 117 
usuários em uma amostra de 1119 estudantes em D enver, Colorado: 113 do gênero masculino e quatro, do feminino. Em 57 (48,7\%) dos estudantes encontraram lesões de tecido mole e/ ou inflamação periodontal e/ ou erosão dentária. 0 uso do TSF variava de 1 a 20 vezes por dia, permanecendo em média 30 minutos cada vez que colocado na boca. A maioria dos usuários usava em torno de dois anos, sendo 20 diferentes marcas de tabaco identificadas. Os autores diagnosticaram quatro diferentes lesões associadas ao TSF: 1. Hiperqueratose ou eritroplasia da mucosa oral; 2. Inflamação gengival ou periodontal; 3. Uma combinação de lesão da mucosa bucal e inflamação periodontal e, 4. Erosão cervical dos dentes. A grande maioria das lesões mucosa era branca, enrugada, e espessa ou saliente, aparecendo nas regiões anatômicas onde o TSF é mais freqüentemente colocado, especialmente na região anterior inferior do vestíbulo bucal.

Para avaliar os efeitos do uso do TSF entre jogadores de beisebol, ERNSTER et al..$^{27}$ em 1990 conduziram um levantamento epidemiológico com 1109 jogadores através de questionários e exames bucais constatando que destes, 39\% eram usuários, a idade média de início do vício era 18 anos e de duração de uso, cinco anos. A leucoplasia bucal estava presente em 46\%(196) dos usuários e 1,4\%(7) dos não usuários, prevalecendo nos usuários com maior horas de uso por dia e entre os que usavam o rapé úmido ao invés do tabaco de mascar. Nos jogadores com leucoplasia bucal foram realizadas biópsias sendo 91 hiperqueratoses benignas e 1 displasia moderada. Recessão gengival e perda de inserção são significantemente maiores entre os usuários. Concluíram que os maiores efeitos do TSF sobre a saúde são leucoplasia bucal e doença periodontal localizada.

KAUGARS et al..$^{43}$ em 1991, selecionaram um grupo de 127 usuários nos quais avaliaram a contribuição de vários fatores de risco no desenvolvimento de lesões bucais. Em 98 não encontraram lesões, mas em 29 (22,8\%) diagnosticaram 
hiperqueratose (23 casos ou 79,3\%) e displasia epitelial (6 casos ou 20,7\%). Selecionaram 33 não usuários para controle e destes, nove apresentaram uma lesão bucal. Uma alteração da mucosa bucal era considerada uma lesão induzida pelo TSF desde que persistisse por mais de sete dias após o interrompimento do uso do TSF. Em relação à idade, os usuários com lesão eram em média mais velhos do que os sem lesão. Outro fator de avaliação foi o número de anos de uso: usuários com lesão tinham usado o tabaco de mascar em média 12,4 anos, comparado aos 8,7 anos dos sem lesão. Os usuários de rapé com lesão tinham usado em média 9,2 anos e os sem lesão 6,9 anos. O cigarro é usado de três a quatro vezes mais pelos usuários de TSF, bem como o consumo de bebida alcoólica, mas tanto o álcool quanto o cigarro não puderam ser considerados fatores de risco nas lesões bucais associadas ao TSF. Os usuários com lesões têm preferência pelo uso do rapé. Os autores concluíram que o desenvolvimento de lesões bucais está relacionado aos anos de uso e freqüência de exposição ao TSF.

Em 1992, DANIELS et al. ${ }^{23}$ relataram que foram examinados 142 espécimes obtidos por biópsia em lesões na mucosa bucal de 133 jogadores profissionais de beisebol usuários de TSF. Foram observados quatro tipos de mudanças epiteliais associadas ao tipo de TSF utilizado, rapé ou tabaco de mascar, mas não foi feita associação entre duração em anos ou horas por dia de uso. 0 uso do rapé associou-se mais freqüentemente ao desenvolvimento de lesões na mucosa bucal e parece ter sido a causa de maior variedade e severidade das mudanças epiteliais do que 0 tabaco de mascar.

Também em 1992, foi realizado estudo com 347 usuários de TSF por KAUGARS et al. ${ }^{44}$; encontraram 45 (13\%) usuários com lesão e destes 35 apresentaram hiperqueratose e 10 displasia epitelial. Estes usuários eram brancos, do gênero masculino e idade média em torno de 29 anos; os usuários com displasia epitelial eram mais velhos que os com hiperqueratose. Também foi constatada 
entre os usuários com lesões bucais uma diminuição na absorção de vitamina $\mathrm{C}$ em torno de 1,5 vez a dos usuários sem lesão. No estudo, afirma-se que usando o TSF 3h/ dia em dois anos, pode ocorrer a hiperqueratose e em 6,6 anos a displasia epitelial. Os usuários com lesão relataram o uso de TSF duas vezes maior que os sem lesão e todas foram detectadas no local de deposição do TSF.

A prevalência e a severidade das lesões na mucosa bucal variam de acordo com a freqüência do uso, tempo de exposição aos tecidos moles, tempo de uso, concentração e tipo de tabaco. Para que os diagnósticos de lesões bucais em usuários de TSF pudessem ser estabelecidos de modo uniforme, o uso de critérios clínicos tornou-se necessário para a classificação dessas lesões. A classificação mais aplicada em análises clínicas referente às leucoplasias induzidas pelo uso do TSF foi elaborada por AXÉL; MÖRNSTAD; SUND STRÖ M em 1976, adotando-se como critérios os aspectos morfológicos e classificando-as em quatro graus:

GRAU 1. Lesão superficial com coloração similar a do tecido circunjacente, apresentando discreto enrugamento, sem espessamento aparente;

GRAU 2. Lesão branca ou amarelada, com rugas ou pregas, sem espessamento aparente;

GRAU 3. Lesão de cor variável entre branco-amarelada e acastanhada, pregueada, com sulcos interpostos de mucosa com coloração normal. O espessamento é clinicamente detectável;

GRAU 4. Lesão de cor variável entre branco-amarelada e acastanhada, com pregas bem delimitadas por sulcos profundos; a mucosa bucal encontra-se bastante espessa. 
Baseados no aumento do uso do TSF nos EUA, no dilema social do uso crônico do álcool e nas evidências epidemiológicas do sinergismo do uso crônico do álcool e do TSF na etiologia de cânceres, SUMMERLIN; DUNIPACE; POTTER $^{76}$, em 1992, realizaram um estudo para determinar os efeitos microscópicos dessas substâncias na mucosa e órgãos de hamsters. Em 80 hamsters sírios dourados machos foram constituídos quatro grupos: em um grupo foi administrado somente tabaco úmido e finamente picado, em outro só álcool, em outro tabaco e álcool e o grupo controle que só recebeu estímulo mecânico com injeção de ar na bolsa mucosa do hamster. Em todos os grupos as substâncias foram administradas apenas uma vez por dia em cinco dias da semana. Após 26 semanas, os hamsters foram sacrificados e seus tecidos e orgãos analisados. 0 único aspecto microscópico estatisticamente significante foi a presença de um aumento na espessura do epitélio no grupo exposto ao tabaco e no do tabaco e álcool, concluindo pela habilidade do TSF induzir aumento na espessura epitelial na mucosa da bolsa dos hamsters. Talvez pelo pouco tempo de exposição ao tabaco e álcool não tenham ocorrido outras alterações mais severas.

Ainda em 1992, a redução no número de células de Langerhans (LC) em lesões de mucosa bucal associadas ao TSF foram estudadas por D ANIELS et al. ${ }^{24}$ Foram examinadas as lesões e tecido normal de 17 usuários de TSF para determinar se as lesões mostravam alteração no número de LC. A redução no número de LC ocorreu em todos os tipos de lesões associadas ao TSF, havendo aumento da espessura epitelial ou mudanças na queratinização. Concluíram que o TSF reduz 0 número das LC no local de contato com a mucosa bucal e pode ser um fator a longo prazo importante na patogênese do carcinoma bucal associado ao TSF.

Em estudo com 245 homens usuários de TSF com idades entre 15 a 77 anos detectados em visitas de rotina a consultórios odontológicos, LITTLE et al..$^{50}$, em 1992 constataram que muitos usavam por acreditar que não fazia mal à saúde e 
outros por não poderem fumar de forma convencional durante o trabalho, lançando mão do TSF como fonte alternativa de nicotina. D os que usavam o TSF há dois anos ou menos, 66\% apresentaram lesões clínicas e comparados a 96\% dos que usavam por 11 anos ou mais. Em relação aos dias de uso por semana, a porcentagem de lesões nos tecidos moles foi de $42 \%$, $74 \%$ e $90 \%$ para os que usavam por dois dias ou menos, de três a seis dias ou os sete dias semanais, respectivamente. Com relação ao número de vezes de uso por dia, 41\%, 77\% e 91\% para uma vez ou menos, de duas a cinco vezes e de seis ou mais, respectivamente. Das lesões, 85\% ocorreram onde o TSF é colocado. De 223 não usuários, 6,3\% tinham lesão na mucosa bucal. Foram detectadas lesões em 66\% dos usuários de TSF que também fumavam e 84\% nos que só usavam o TSF. Os autores acreditam que isso ocorra porque os usuários que fumam consomem menos TSF. A absorção sistêmica e os níveis plasmáticos de nicotina foram similares para fumantes e usuários de TSF.

Procurando avaliar a prevalência de uso do TSF com o desenvolvimento de carcinoma de células escamosas (SCC) e carcinoma verrucoso (VC), em 1992 LINK; KAUGARS; BURNS ${ }^{49}$ estudaram microscopicamente as lesões associadas ao TSF. De 874 carcinomas de células escamosas 1,4\% tinham história de uso de TSF e de 129 casos de carcinoma verrucoso, 7,7\% associavam-se ao uso do TSF. Ambos carcinomas foram diagnosticados em usuários com idade mais avançada, cerca de uma década de diferença dos não usuários, o que para os autores, sugere a necessidade de uma exposição a longo prazo para desenvolver o carcinoma. Há diferença na localização anatômica do SCC e do VC quando se comparam usuários com não usuários. Em não usuários, o SCC é mais comum no assoalho bucal e 0 VC na gengiva, enquanto nos usuários, ambos ocorrem mais na mucosa jugal. 0 alto grau de diferenciação microscópica e faixa etária maior na associação do uso do TSF com o SCC e o VC, podem indicar que o TSF é menos carcinogênico que 
outros fatores de risco, pois requer um longo período de tempo até que 0 carcinoma seja evidenciado clinicamente. A especificidade da área anatômica faz do TSF um fator causal para o desenvolvimento de alguns casos de carcinomas bucais.

Com o intuito de analisar os possíveis efeitos do TSF, foram revisados por WRAY et al. ${ }^{86}$ em 1993, os registros de 128 pacientes com carcinoma bucal que haviam usado o TSF exclusivamente e nenhum outro carcinógeno, bem como os de 32 pacientes que além do TSF, fumavam e consumiam bebidas alcoólicas. A maioria era de homens brancos, idosos, em média com 78 anos de idade. Nos dois grupos, diferia-se significativamente a localização dos mesmos; no grupo só do TSF, 28\% localizavam-se na superfície da mucosa jugal, 33\% na superfície alveolar e 19\% em ambas as áreas, sendo que destes $80 \%$ estavam onde o TSF era colocado, entre a bochecha e a gengiva, no outro grupo, 42\% dos tumores estavam na mucosa jugal e alveolar, 16\% na língua, 13\% no assoalho bucal, 23\% na área das amígdalas e 1\% no palato. Após tratamento cirúrgico, radioterápico, quimioterápico ou associados houve recorrência de lesões ou metástases em torno de oito meses. Desses pacientes, $47 \%$ sobreviveram por três anos e 37\% por cinco anos, concluindo que, para que se desenvolva um câncer, a exposição ao agente carcinogênico deve ser prolongada, como neste estudo em que $78 \%$ (dos 128) usaram o TSF por mais de 40 anos.

JOHNSON; SQUIER ${ }^{41}$, em 1993, notaram que paralelo ao declínio do número de fumantes, pelo conhecimento público sobre os efeitos prejudiciais do

cigarro, ocorreu o aumento do uso do TSF entre crianças e adolescentes, pois no passado o uso prevalecia em zonas rurais e homens em torno dos 50 anos, tendo 
crescido em áreas metropolitanas e entre adolescentes e jovens do sexo masculino. 0 uso do TSF aumentou o risco de desenvolvimento de recessão gengival, leucoplasia e câncer bucal, especialmente no local onde se coloca o TSF. Estima-se que nos EUA 12 milhões de pessoas sejam usuárias de TSF e que dos usuários atuais 46,3\% apresentam leucoplasia no local de escolha para o uso, o vestíbulo anterior inferior. As lesões na mucosa bucal mostram-se brancas, enrugadas com aparência clínica de leucoplasia com variáveis graus de espessamento da mucosa. Para os autores, a chance dos usuários terem alterações na mucosa bucal é seis vezes maior do que os não usuários.

Com a finalidade de investigar a incorporação e 0 metabolismo da nicotina em usuários do TSF sueco, ANDERSON; BJÖRNBERG; CURVALL ${ }^{2}$ realizaram estudo em 1994 comparando as alterações ocorridas na mucosa bucal e correlacionando a exposição a incorporação dos compostos do tabaco em 22 usuários de rapé úmido, 23 de TSF em sachês e nove de tabaco de mascar. A média de idade foi maior para os usuários do tabaco de mascar, em torno dos 50,4 anos, 0 maior consumo diário foi dos usuários do rapé úmido (20,8g/ dia), o número de horas por dia que o tabaco ficava na boca foi semelhante para os três grupos (de 12,3 a 13,1h) e o número de anos de vício regular foi maior para o grupo do rapé úmido (14,5 anos). A incorporação média de nicotina medida pelo equivalente de nicotina excretada em 24 horas, para os usuários de rapé úmido foi de 35mg sendo $50 \%$ maior para os usuários do tabaco de mascar. A concentração média de cotinina na saliva foi de 300ng/ $\mathrm{ml}$ para os usuários de rapé úmido, similar ao encontrado em fumantes, sendo também 50\% maior para os usuários do tabaco de mascar. Os usuários do TSF em sachês mostraram lesões menos severas que os do rapé úmido, predominando lesões de grau 1 e 2, enquanto os usuários do rapé úmido tiveram mais lesões de grau 3 e os do tabaco de mascar tiveram alterações na mucosa bucal do tipo leucoedema e lesões de grau 1 e 2. 
Em 39.206 alunos de 5 e 17 anos nos EUA, KLEINMAN; SWANGO; PINDBORG ${ }^{46}$ em 1994, avaliaram a presença de lesões bucais, predominando no lábio o herpes labial em 77,5\% dos casos e, na língua 76,8\%, a língua geográfica. Em 70,7\% das lesões da mucosa bucal e 86,5\% da mucosa labial havia associação com o TSF e aftas recorrentes. A prevalência de lesões na mucosa bucal de crianças de 12 a 17 anos que usavam o tabaco de alguma forma era 15,1\% ou três vezes mais do que as não usuárias. A prevalência de lesões para adolescentes que relatam apenas o uso do "snuff" foi de 38,5\%. 0 gênero masculino tem 1,4 vez mais lesões que o feminino e os brancos, duas vezes mais que os negros e outras raças.

Realizando questionários com alunos de uma escola pública secundária em Iowa, EUA, DAUGHETY et al. ${ }^{25}$, no ano de 1994, observaram em 821 meninos entrevistados: $52 \%$ já haviam usado o TSF pelo menos uma vez, independente da forma. 0 rapé úmido era a forma preferida, excedendo de três para um o uso do tabaco de mascar. Foram selecionados 183 meninos que usaram o TSF mais que 20 vezes, a ocorrência de lesões era bastante relatada nos que usavam o TSF diariamente e que mantinham o tabaco mais que 15 minutos na boca, principalmente os que usavam sempre no mesmo local. Em 35\% dos meninos depois que achavam uma lesão, paravam de usar pelo menos por um período, 24\% apenas mudavam o local de deposição e continuavam usando, 12\% se aconselhavam com algum amigo e 1,7\% contava para os pais sobre seu problema. Os autores concluem que os meninos que apresentam lesão bucal são mais conscientes quanto aos perigos do TSF e são mais receptivos a parar com 0 vício, sugerindo que exames bucais de rotina são oportunidades para detectar lesões em desenvolvimento, bem como para discutir experiências com lesões, avisar sobre os riscos do TSF e planejar uma estratégia para deter o vício.

Em estudo realizado com 296 mulheres de Bangladesh em 1994, SUMMERS; WILLIAMS; CURZO N ${ }^{77}$ constataram que 276 (93\%) eram originárias 
de áreas rurais de Bangladesh, 144 nunca tinham ido à escola, nove (3\%) tinham estudado nove ou mais anos, sendo que 142 (48\%) eram totalmente analfabetas. Enquanto 11 (4\%) deixavam o "pan" na boca, 282 (95\%) mascavam "pan" e 13 (4\%) não usavam nenhum tipo. 0 consumo de uma a cinco porções para mascar diariamente era de $37 \%$, mas $2 \%$ mascavam em média mais que 26 vezes por dia, 0 vício era adotado entre os 3 a 35 anos. Em relação ao uso, 34\% diziam ser apenas um hábito, 22\% achavam refrescante e agradável, 12\% afirmavam que era bom para os dentes e gengivas, agindo como preventivo, 11\% achava que auxiliava a digestão e 6\% consideravam que tinha um efeito antiinflamatório.

Algumas mulheres acreditavam que os lábios ficavam mais atrativos, pois vermelhos. Quando acabam de mascar, 59\% cospem, 24\% engolem, 17\% deixam no sulco jugal e 3\% têm o vício de dormir com o "pan" na boca.

Para GREEN ${ }^{31}$, conforme descrição em 1995, o objetivo da indústria do tabaco são homens de 10 a 25 anos ou mais, mas acabam atraindo crianças de cinco e seis anos. A ênfase dada às propagandas, mostra o TSF como alternativa segura e gostosa para o cigarro, utilizando atletas famosos, o que faz com que as crianças queiram parecer, imitar seus ídolos e heróis e usem o TSF, aumentando a venda do tabaco de mascar e do rapé em 200\% nos últimos dez anos. A área rural representa a maior taxa de uso. O TSF contém nicotina, um alcalóide que vicia e afeta a pressão sangǘnea, imediatamente afeta o sistema nervoso central como um estimulante, depois causa depressão e desaparece, essa sensação de alto e baixo vicia.

A pressão sanguínea do usuário de TSF é maior do que dos fumantes e em médio prazo pode-se ter problemas gengivais, manchas nos dentes e 
leucoplasias. Em longo prazo, pode-se ter carcinomas de células escamosas de língua e mudanças celulares que podem levar a outros cânceres. GREEN ${ }^{31}$ afirma ser o TSF pior que o cigarro por ser colocado em contato direto com os tecidos bucais e absorvido.

Em estudo realizado por TOMAR; GIOVINO; ERIKSEN ${ }^{81}$ nos EUA, no ano de 1995, avaliando as marcas preferidas pelos jovens usuários de TSF e mudanças como duração, freqüência e intensidade de uso, observaram que as marcas: Skoal, Copenhagen, Kodiak e Skoal Bandits, são as preferidas por 80\% dos jovens e com 0 aumento da duração, freqüência e intensidade de uso aumenta 0 uso da marca Copenhagen. Os usuários de Copenhagen e Kodiak relatam mais sobre o uso do TSF e os sintomas da retirada de nicotina do que os usuários de Skoal e Skoal Bandits devido à dificuldade que eles têm de parar o uso. Concluindo, os autores que os usuários preferem o rapé úmido a outras formas do TSF e inicialmente usam marcas com menos nicotina e posteriormente trocam por marcas com altas concentrações, particularmente Copenhagen.

No ano de 1995, ANDERSON; AXÉLL; CURVALL ${ }^{1}$, conduziram um estudo com dois grupos de pessoas: grupo 1 com 24 pessoas (média de idade 37 anos) que usaram seu TSF habitual por duas semanas e na $3^{\text {a }}$ a $12^{\underline{a}}$ semana foi trocado por uma marca de TSF com menos nicotina e o grupo 2 com 18 pessoas (idade média 36,6 anos) que usavam o TSF com menos nicotina pelo menos há um ano e foram seguidos por duas semanas, antes do início do estudo todos passaram por um exame da cavidade bucal em uma clínica odontológica. Houve um significante aumento no consumo diário no grupo 1 quando trocou-se o TSF habitual por um com menos nicotina, mas houve declínio na admissão de nicotina diária. Ocorreram também alterações nas reações da mucosa bucal devido à redução na severidade das lesões com redução no grau de brancura e espessamento clínico; essas conclusões foram obtidas após análise de exames clínicos, amostras 
de saliva e urina que foram realizadas nas semanas 1 e 2 nos dois grupos e na $4^{\underline{a}}$, $8^{\underline{a}}$ e $12^{2}$ semanas no grupo 1.

Em estudo realizado em Kaohsiung, Taiwan, CHEN; SHAW ${ }^{18}$ no ano de 1996, através de entrevistas realizadas por telefone, investigaram a prevalência de uso do betel de mascar entre os moradores com 15 anos ou mais de idade. Das 1.162 que responderam as entrevistas, 1.008 (86,7\%) nunca tinham usado o "betel" de mascar, 145 homens e nove mulheres usavam; destes 154 usuários 33 (21,8\%) usavam diariamente, todos homens. A média de idade era de 36,79 anos; 61,8\% das pessoas receberam de 7 a 14 anos de educação, 27,4\% estudaram seis anos ou menos e apenas $10,8 \%$ terminaram a universidade.

Observaram os autores que as pessoas do gênero masculino que fumavam e consumiam bebidas alcoólicas tendiam a mascar o betel, concluindo que esses são importantes fatores na predisposição do comportamento de mascar 0 betel. Sugerem a prevenção pelos efeitos negativos do betel semelhantes ao fumo e TSF e no futuro pode ser uma ameaça à saúde pública, requerendo mais estudos sobre o mecanismo de carcinogênese e da fibrose submucosa associada ao betel de mascar e seus aditivos, desenvolvendo-se para isto um comportamento social que substitua 0 vício de mascar betel ${ }^{18}$.

Com a finalidade de analisar os efeitos bucais decorrentes do uso do TSF, em 1997, ROBERTSON; WALSH; GREENE ${ }^{66}$ conduziram um estudo com 
jogadores de beisebol, comparando esses efeitos entre os usuários e os não usuários. A prevalência de leucoplasia mostrou-se significativamente maior entre os usuários do que nos não usuários e 90\% para os que usavam o rapé ao invés do tabaco de mascar, localizando-se nas áreas onde colocado na boca. Em relação a recessão gengival, abrasão e cáries cervicais e radicular, pigmentação dentária e desgaste oclusal, os usuários apresentaram maior prevalência. Quanto ao desempenho do atleta não houve diferenças entre os grupos e detectaram que cerca de $40 \%$ desses jogadores usavam o TSF, cerca de 50\% deles apresentaram leucoplasias, enquanto menos de $2 \%$ dos não usuários apresentaram-na. Usuários de rapé tem maior risco de desenvolver lesões e mais severas do que os usuários do tabaco de mascar; o aumento da prevalência de recessão gengival leva ao aumento de cárie e abrasão cervical nos usuários, bem como desgaste oclusal e pigmentação dentária.

Em relato de 1977, HENNING FIELD; FANT; TOMAR ${ }^{37}$ ressaltam que o uso do TSF surge como um problema de saúde pública nos EUA, vicia e é carcinogênico. O número de usuários aumentou rapidamente, provocando mudanças abruptas no perfil demográfico dos usuários; por volta de 1970 eram homens com 65 anos de idade ou mais e que preferiam o tabaco de mascar, já na década de 80 e 90, a faixa etária de maior uso é de 18 a 24 anos, sendo a preferência pelo rapé úmido. O TSF leva a tolerância e sintomas da síndrome de abstinência, 0 que caracteriza a dependência, o vício. Os produtos de TSF diferem em sua composição, na liberação de nicotina e na forma de uso. 0 mais usado atualmente é o rapé úmido que passa por sofisticadas técnicas de fabricação e dosagem de nicotina, o pH alcalino dos charutos, cachimbos e produtos do TSF fazem com que a nicotina seja rapidamente absorvida pela mucosa bucal e nasal, o cigarro tem $\mathrm{pH}$ ácido devendo a fumaça ser inalada para uma efetiva absorção. 0 conteúdo de 
nicotina variável nos produtos do TSF visa atender novos usuários e possui sabores para disfarçar o gosto do tabaco, obtendo novos consumidores.

HASSÉUS et al. ${ }^{35}$ em 1997, realizaram um estudo "in vitro" com 0 extrato de rapé úmido sueco, alcalóides e nitrosaminas para avaliar os efeitos sobre as respostas mitogênicas das células $T$, usando células epiteliais, incluindo as células de Langerhans, da mucosa bucal de ratos. Este estudo "in vitro" mostrou que 0 rapé úmido pode levar a uma imunossupressão na proliferação das células $\mathrm{T}$, sendo esse efeito maior quando o extrato do rapé úmido for usado em vez dos componentes isolados. A implicação "in vivo" dessas observações é que a exposição da mucosa bucal ao rapé pode induzir uma imunossupressão, não apenas sobre os efeitos das células de Langerhans como também das células T, concluindo que a exposição ao tabaco em longo prazo pode causar agressões aos diferentes sistemas de defesa da mucosa, incluindo o sistema imunológico.

Também em 1997, CHASE $^{16}$ publicou que o tabaco de mascar tem estado associado com adultos jovens e mais velhos. Atualmente o segmento demográfico que apresenta maior aumento de uso do TSF está representado pelo gênero masculino, na faixa etária compreendida entre 10 e 24 anos de idade. Esta alarmante tendência está no mínimo relacionada com os dez anos anteriores de forte promoção do uso do TSF, o qual supostamente seria uma alternativa inofensiva ao uso do cigarro. Cita ainda que para os jogadores jovens, ter uma lata de TSF no bolso de seus uniformes, os fazem parecer "machos" e como resultado disso, pelo menos um fabricante de chiclete de mascar, lançou seus chicletes em latas semelhantes a do tabaco para parecer que a pessoa é usuária do TSF. Em outro trabalho, no mesmo ano, $\mathrm{CHASE}^{17}$, escreve sobre o uso do tabaco de mascar e 0 câncer bucal e relata que nos EUA foram diagnosticados 33.000 casos de câncer bucal em 1996, e aproximadamente metade desses pacientes morrerão nos próximos cinco anos e a outra metade sobreviverá somente após sofrer as agonias 
da quimioterapia, radiação e/ ou cirurgia para não precisar descrever 0 desfiguramento facial resultante do tratamento. Será que estes dados não seriam importantes para influenciar pelo menos a metade dos jovens americanos que usam o TSF, pergunta 0 autor.

A presença de lesões de TSF na mucosa bucal de adolescentes representa forte indício do crescimento do risco de câncer bucal para TOMAR et al. ${ }^{80} \mathrm{em}$ 1997. As lesões são associadas com a duração, freqüência e o tempo diário de uso do TSF. $O$ uso do álcool e tabaco é o maior fator de risco para o desenvolvimento de câncer na cavidade bucal e faringe, sendo responsável por quase 75\% dessas neoplasias. Microscopicamente, essas lesões causadas pelo uso do TSF são caracterizadas por hiperqueratinização e vascularização do epitélio, acantose ou espessamento da camada espinhosa da epiderme e proliferação de células inflamatórias. Clinicamente, apresentam mudanças na coloração e textura da mucosa. Em estudo, com uma amostra em torno de 17.000 estudantes, os autores constataram que $1,5 \%$ dos estudantes entre 12 e 17 anos tinham pelo menos uma lesão, sendo que 3,9\% eram do gênero masculino e brancos, $65 \%$ das lesões foram localizadas na região vestibular direita ou esquerda e $24 \%$ na região anterior inferior, 4,8\% na mucosa bucal direita ou esquerda, 3\% na mucosa labial superior, 1,5\% na gengiva inferior ou superior e 1,7\% em outras áreas anatômicas.

WINN $^{85}$, pretendendo demonstrar os efeitos decorrentes do uso do TSF sobre os riscos cardiovasculares e câncer bucal associados à nicotina e outros constituintes do TSF, em 1997, sugeriu a hipótese da associação de outros tipos de cânceres como os de próstata, laringe, esôfago, colo, reto, pâncreas e outros ao TSF, pela penetração dos carcinógenos do TSF na circulação, ficando estes disponíveis para os tecidos do corpo, aumentando o risco de câncer em outros locais. Outros estudos devem ser feitos, mas os usuários do TSF devem ser 
advertidos para os riscos de câncer bucal e o potencial papel do TSF no desenvolvimento de outros cânceres e doenças cardiovasculares.

A "Food and Drug Administration", em 1997, considerou a nicotina contida no cigarro e no TSF como envolvidas no comprometimento das estruturas ou funções do corpo, levando ao vício e outros efeitos farmacológicos, sendo portanto a nicotina considerada como uma droga que leva o usuário à dependência ${ }^{45}$.

MERAW; MUSTAPHA; ROGERS ${ }^{56}$, em 1998, denominou a lesão da mucosa bucal característica do uso do TSF como "lesão do mascador de tabaco" ou "queratose do rapé", que ocorre nas áreas onde o TSF é colocado na mucosa bucal, com potencial para transformação maligna. Para eles, a cessação do vício pode parar a progressão dos efeitos prejudiciais à saúde, e recomenda uma biópsia se a lesão não começar regredir em 14 dias e adverte que a melhor prevenção está em nunca usar o tabaco.

WALSH et al. ${ }^{83}$, em 1998, realizaram um estudo piloto com dois grupos de jogadores profissionais de beisebol no Arizona, sendo que os treinadores receberam treinamento adicional de duas horas/sessão sobre os métodos de comportamento e terapia substituta de nicotina para ajudar os atletas que tentassem cessar 0 vício. Os atletas participantes responderam a questionário sobre sua saúde geral, uso de tabaco, tendência de uso, tentativa prévia de cessação e métodos usados, interesse em receber ajuda para parar e terapia substituta de nicotina. 
D epois passaram por um exame bucal observando-se as lesões por um profissional que falava para cada um sobre os problemas associados ao uso do TSF, as formas de uso, oferecia ajuda para parar o vício e um manual de auto-ajuda e os que desejassem parar de usar, após o exame bucal e informações do cirurgiãodentista, passavam pela higienista para instruções e desenvolvimento de um plano para parar: se 0 atleta queria usar um substituto bucal sem tabaco ou terapia com substitutos de nicotina. Como resultado de 304 atletas que responderam 0 questionário, 95 (31\%) eram usuários, 22 (7\%) ex-usuários e 187 (62\%) não usuários. Entre os 95, 61 (64\%) usavam diariamente e 34 (36\%) eram usuários sociais (semanais ou de duas a três vezes por mês). Em 56\% dos usuários usavam por cinco ou mais anos, 14\% mais que dez anos, mais da metade dos usuários, 53\% usavam só em temporadas, $71 \%$ usavam exclusivamente 0 rapé úmido e $47 \%$ preferiam a marca Copenhagen. Em 71\% ficavam com o TSF na boca ou 0 mascavam mais que dez minutos e $24 \%$ usavam mais que cinco vezes por dia. D os 95 usuários examinados, 53 (56\%) tinham lesões de mucosa bucal associadas ao TSF, sendo que destes 41 (77\%) usavam diariamente e 12 (23\%) são usuários sociais. Em 45\% dos usuários responderam que queriam ajuda para parar naquele dia, 71\% quiseram orientação da higienista imediatamente após o exame bucal e $49 \%$, destes $71 \%$, marcaram uma data para parar, os treinadores relataram no final da temporada que dos 67 usuários que quiseram orientação após o exame bucal, seis (9\%) pararam de usar o TSF e citaram como a mais útil parte do programa a motivação, o exame bucal, bem como o encontro dos jogadores com um especialista sobre cessação de uso que esteve presente durante os procedimentos. Concluindo, os autores consideraram muito importante o papel do cirurgiãodentista e da higienista nesse processo. 
Analisando os hábitos de higiene bucal de usuários de tabaco, ANDREWS et al. ${ }^{3}$ em 1998, em uma amostra de 34.897 pacientes odontológicos, com idade entre 15 e 94 anos, observaram que 30.136 não eram usuários de TSF, 4.029 usavam cigarro, 632 o TSF e 100, tanto cigarro como o TSF, apenas uma mulher usava o TSF. O s não usuários, tanto masculino como feminino, escovavam os dentes e usavam fio dental com mais freqüência que os usuários. Em relação à escovação não há diferença na freqüência entre os usuários de cigarro ou os do TSF ou de ambos, já em relação ao uso do fio dental os que usam cigarro usam mais do que os usuários do TSF. Em relação à recomendação da AD A em escovar pelo menos duas vezes por dia, não há diferença entre os usuários de cigarro e os de TSF, já quanto a usar o fio dental pelo menos uma vez ao dia , os do cigarro $(23,2 \%)$ e os do TSF $(14,7 \%)$, relatam também que os usuários do TSF apresentam mais sangramento gengival (17,7\%), recessão gengival (26,4\%), lesões bucais (4\%) e menos manchas nos dentes $(21,2 \%)$ e halitose $(9,3 \%)$ do que usuários de cigarro $10,6 \%, 24 \%, 2 \%, 32,9 \%$ e 11,9\%, respectivamente. Concluíram ainda que 0 número de cigarros, sachês ou porções de TSF, está em uma relação de uso inversa à freqüência de escovação para homens e mulheres que usam cigarro e para os homens que usam o TSF.

De acordo com PROKHOROV et al. ${ }^{62}$ em relato de 1998, houve nos EUA um aumento de dez vezes do uso do TSF entre 1970 e 1980. Um dos efeitos deletérios desse uso é a presença de leucoplasia na mucosa bucal do usuário, sendo a leucoplasia considerada uma lesão cancerizável com potencial de transformação maligna em cinco anos em torno de 5\%. Para eles, o TSF está associado com cânceres de gengiva, boca, faringe, laringe e esôfago, e pode também elevar a pressão sangüínea e exercer um papel no desenvolvimento de doenças cardiovasculares e derrame cerebral. Embora haja muitas similaridades entre 0 cigarro e o TSF, eles diferem no método de liberação de nicotina e no perfil do 
usuário. 0 fato de o TSF ser considerado menos prejudicial do que o cigarro e ser uma alternativa ao uso do cigarro, o torna mais perigoso.

Com o objetivo de avaliar a resposta de lesões leucoplásicas após seis semanas de suspensão do uso do tabaco, MARTIN et al. ${ }^{53}$ em 1999, realizaram estudo com 3.051 cadetes, do gênero masculino da base militar da Força Aérea dos EUA. Realizaram exame bucal inicial e após seis semanas e um questionário sobre marcas e tipos de tabaco usado, tempo de uso em meses e número de dias desde 0 último uso. Encontraram 302 (9,9\%) usuários e desses 119 (39,4\%) tinham lesões leucoplásicas, 96,9\% dessas lesões foram encontradas no fundo do sulco vestibular inferior, mais comumente no lado esquerdo (45,4\%). Q uanto à gravidade das lesões, 61,5\% eram nível 1, 35,5\%, nível 2 e 3\%, nível 3. Após seis semanas, 109 dos 119 pacientes com leucoplasias foram reexaminados e em 106 pacientes as áreas leucoplásicas tinham se solucionado por completo clinicamente. Constataram que a leucoplasia estava presente em 15\% dos pacientes que usaram TSF de 1 a 12 meses e em 71\% dos que usaram mais que 48 meses, os usuários da marca Copenhagen tiveram maior risco de desenvolvimento comparado aos não usuários, já os que usavam a marca Skoal e Kodiak tiveram riscos semelhantes aos não usuários. Os autores concluíram que se um jovem saudável do gênero masculino deixar de usar todos os produtos de tabaco durante seis semanas, a maioria das lesões se resolve clinicamente sem a necessidade de uma biópsia. No caso dos pacientes que usaram o TSF de 10 a 12 anos e tinham lesões graves, observaram que o tempo de uso, quantidade por dia, tipo e marca também influem na presença de leucoplasia bucal.

Relata ZAIN et al. ${ }^{88}$, em 1999, com a finalidade de unificar as várias formas de fumo e definir critérios para as lesões associadas ao vício, realizou-se um "workshop" em Kuala Lumpur, Malásia, contando com a participação de 22 
autores de 11 países, entre eles Índia, China, Malásia, Japão, África do Sul, Reino Unido e Noruega. Como o TSF é um tipo de fumo que inclui diferentes misturas como noz de areca, outras ervas com compostos aromáticos, pétalas de rosa enroladas em folha de betel, cal, neste workshop foi recomendado o termo "quid" para definir uma substância ou mistura de substâncias que colocada na boca, mascada ou permanecendo em contato com a mucosa contendo usualmente tabaco e/ ou noz de areca, natural ou de alguma forma manufaturada ou processada. Quanto às lesões da mucosa bucal associadas ao vício de uso do "quid", foram sugeridas duas categorias. A primeira corresponde às lesões dispostas difusamente envolvendo mais de um local da mucosa, devido a trauma mecânico ou químico pelo fumo, como a "mucosa do mascador", com tendência a descamar-se, deixando uma área subjacente pseudo membranosa ou enrugada. Em uma segunda categoria se encontram as lesões localizadas em áreas da mucosa onde o "quid" é depositado, caracterizando-se por uma ou mais das seguintes alterações: mudança da coloração normal, aparência enrugada, espessamento da mucosa, descamação ou não do epitélio e presença de ulcerações; entre essas lesões podemos citar a fibrose submucosa oral, as lesões liquenóides associadas ao betel e as denominadas lesões induzidas pelo fumo, dentre as quais a leucoplasia.

O uso do tabaco é também um fator causal no desenvolvimento de estomatites nicotínicas, sangramento gengival, recessão gengival, gengivite ulceronecrosante aguda, aumento na formação de cálculo dentário, halitose e manchas dentárias. Em adição a esses problemas de saúde bucal, o uso do tabaco é responsável por 20 a 25\% de todas as mortes nos EUA e Canadá e 20 a 30\% das mortes por problemas cardiovasculares e câncer. Apesar dos riscos à saúde serem atribuídos ao fumo, 26\% dos americanos e $29 \%$ dos canadenses continuam fumando, de acordo com CAMPBELL; SLETTEN; PETTY ${ }^{13}$ em 1999. 
As diferentes formas de uso do tabaco são responsáveis pela aparência, local e freqüência das lesões associadas ao vício do tabaco. MIRBOD; AHING ${ }^{59}$ no ano de 2000 relatam sobre as lesões não malignas decorrentes do vício como a coloração marrom escura ou preta na região cervical dos dentes associada aos produtos da combustão do cigarro, abrasão na superfície vestibular do dente pela acomodação do TSF ou da superfície oclusal quando o tabaco é mascado. A estomatite nicotínica associada ao cachimbo e as leucoplasias que desaparecem quando o uso do TSF é abandonado.

No mesmo ano, MIRBOD; AHING ${ }^{60}$ com relação às lesões malignas afirmam que os cânceres bucais representam 3-4\% de todos os cânceres, sendo 0 mais comum o carcinoma de células escamosas. O TSF contém nicotina, importante carcinógeno na iniciação e promoção de específicos tipos de câncer como o carcinoma de células escamosas e o carcinoma verrucoso.

\subsection{PROGRAMAS DE INTERVENÇÃO}

\section{E O PAPEL DO CIRURGIÃO DENTISTA}

Apesar do consumo per capita de cigarros nos EUA tenha estado em declínio nos últimos 20 anos, o uso do TSF, seja rapé ou de mascar, tem aumentado dramaticamente conforme LITTLE et al. ${ }^{51}$ em 1992. Entre 1970 e 85, a produção de rapé nos EUA aumentou $56 \%$, e a do tabaco de mascar 36\%, isto significa um milhão a mais de usuários de TSF em 1985, comparando-se a 1970, enquanto em contrapartida não houve aumento no total de usuários de cigarros no 
período mencionado. 0 câncer bucal alcança cerca de 3\% de todos os cânceres nos EUA e com o uso cada vez maior do TSF, espera-se uma incidência também cada vez maior e significante. Visitas a consultórios odontológicos são oportunidades únicas para orientações e avisos para cessar o uso do TSF, salientando o importante papel da higienista na educação do paciente, incluindo informações sobre os efeitos deletérios do TSF à saúde bucal.

No mesmo ano, LITTLE et al. ${ }^{50}$ realizando estudo com 245 homens usuários de TSF em visitas de rotina a consultórios odontológicos, concluíram que os cirurgiões-dentistas podem exercer um grande serviço orientando seus pacientes a parar de usar o TSF e reforçar, informando como a lesão regride após cessado 0 uso.

Dentro das próximas décadas os EUA, terá uma nova face epidemiológica do câncer bucal devido ao uso do TSF entre os adolescentes, pois o TSF é tão perigoso e mortal como os outros produtos do tabaco. Os profissionais de saúde têm o papel de combater o uso do TSF, os que trabalham com saúde são educados sobre o verdadeiro risco do "tabaco de cuspir" e a prevenção do uso e ajuda às pessoas pararem com seus vícios. Os cirurgiões-dentistas tratam $75 \%$ dos jovens americanos entre 5 a 17 anos de idade, sendo essa uma oportunidade para ajudá-los ${ }^{55}$.

JOHNSON; SQUIER ${ }^{41}$, em 1993, relataram que a porcentagem de usuários de TSF, praticamente dobrou de 1980 para 1984, estimando que os EUA possua de 10 a 12 milhões de usuários, salientando o importante papel dos cirurgiões-dentistas na detecção e educação do paciente, devendo perguntar sobre 0 uso de todas as formas de tabaco, incluindo quantidade e duração do uso na anamnese. As lesões leucoplásicas tendem a desaparecer clinicamente após duas ou 
três semanas ao cessar o uso do TSF, se persistir uma biópsia deve ser providenciada. A mais séria implicação em saúde pública do uso do TSF está na probabilidade do aumento do risco de câncer bucal resultante do longo tempo de uso do TSF por jovens, principalmente do gênero masculino.

Para avaliar a eficácia da intervenção sobre a cessação do uso do TSF, STEVENS et al. ${ }^{74}$ em 1995, com uma amostra de 518 homens usuários, analisaram cuidados de rotina por cirurgiões-dentistas e higienistas. Em 273 pacientes e em outros 245 pacientes que além desses cuidados receberam intervenção, entre elas: material de auto-ajuda, vídeos, informações sobre os riscos à saúde do uso do TSF, orientações para parar o vício, rápidos conselhos da higienista dental, recebiam um número de telefone de ajuda 24 horas e um kit contendo substitutos bucais como chicletes, uma lata com folha de menta moída sem tabaco e conselhos de como parar. D essa amostra, 50\% tinham menos que 30 anos e 16\% tinham entre 15 e 19 anos de idade, 96,2\% eram brancos e 1,4\% negros. Dos 245 pacientes, 78,6\% tinham lesões na mucosa bucal e destas $85 \%$ estavam localizadas onde o tabaco era colocado, comparando o grupo que recebeu intervenção só os cuidados de rotina, a proporção para abstinência do TSF foi aos três meses de 32,2\% e 21,3\% e aos 12 meses $33,5 \%$ e $24,5 \%$, respectivamente, concluindo os autores sobre a eficácia da intervenção dos cirurgiões-dentistas e higienistas dentais nas consultas de rotina.

Com 0 intuito de avaliar um programa que ajudasse a maior liga de jogadores dos EUA a parar de usar o TSF, GREENE et al. ${ }^{32}$, em 1994, selecionaram uma amostra de jogadores e os dividiu em dois grupos, $A$ e $B$, sendo que no A foi realizado exame bucal nos participantes e responderam um questionário e uma palestra de cinco a dez minutos sobre a cessação do uso do tabaco. 0 grupo B recebeu o mesmo tratamento e mais cinco a dez minutos de orientações com um cirurgião-dentista, mostrando fotos de lesões em outros 
jogadores. O btiveram como resultado que 72,2\% dos examinados eram usuários na época do exame, 65\% usavam rapé, 53\% tinham lesão na mucosa bucal na área onde o tabaco era depositado e 51\% apresentaram recessão gengival; este grupo B recebeu ainda um aconselhamento individual de uma higienista dental de como parar de usar o TSF. Em 54 usuários foram examinados duas vezes e desses cinco do grupo B tinham parado de usar o tabaco e $46 \%$ tinham tentado parar e $11 \%$ do grupo A também tentaram. Os autores afirmaram que programas envolvendo exames bucais, conselhos para parar 0 vício associados a orientação comportamental podem efetivamente declinar o uso do TSF entre os jogadores.

Desde que, os programas de prevenção do uso do TSF podem ser seguidos como os de drogas e álcool, os mesmos níveis de prevenção são aplicados: prevenção primária que visa adiar ou excluir a iniciação do envolvimento; secundária que identifica pessoas nos estádios iniciais de comportamento duvidoso associado ao uso e à terciária com 0 completo fim do uso. Para RINCHUSE ${ }^{64}$ (1995), o cirurgião-dentista e a higienista dental podem atuar em todos os níveis, salientando que as visitas aos cirurgiões-dentistas são mais regulares do que em outros profissionais de saúde, aproveitando essas visitas e as subseqüentes para reforçar as informações e conselhos podendo providenciar material educacional. Devido ao fato dos jovens não se preocuparem com problemas num futuro distante, os cirurgiões-dentistas e higienistas podem influenciar em efeitos a curto prazo, falando sobre a redução na capacidade atlética, o custo do uso dos produtos do tabaco, a "sujeira" do vício, a halitose, manchas nos dentes, etc. Aproveitando as visitas dos pacientes, orientar sobre outras manifestações bucais que são freqüentes: recessão gengival, gengivites, abrasão dentária e leucoplasia. 
YANG et al. ${ }^{87}$ no ano de 1996, conduziram estudo em Taiwan, com alunos de ginásio (G-1) e de uma escola técnico-profissional (G-2); no G-1 havia 1,9\% usuários sendo 3,4\% meninos e 0,4\% meninas; no G-2, 10,2\% eram usuários. Os autores relatam que o vício provavelmente persista pela sensação de bem-estar que causa. O uso entre mulheres é menor, pois estas consideram o uso desfigurante, causa halitose e deixa os dentes sujos. 0 vício aumenta com a idade, associam 0 uso a estudantes masculinos de baixo nível escolar, problemas de comportamento, experiências com bebidas alcoólicas, fumo e drogas, influência dos pais e amigos mais velhos. Esses autores, ressaltam que programas preventivos devem ser implantados com prioridade para adolescentes e intervenção preventiva através de educação e habilidade social, pois podem aumentar o conhecimento sobre substâncias psicoativas.

Pelo alto nível de nicotina nos produtos do TSF, rapidamente vicia; os membros da equipe de saúde devem perguntar às crianças, adolescentes e adultos sobre o uso do TSF, pois quanto mais cedo a intervenção for realizada, mais efetiva seráa $^{20,83}$.

HATSUKAMI; BOYLE ${ }^{36}$, em 1997, através de revisão de literatura, discorreram sobre a prevenção e tratamento de usuários de TSF, mostrando a importância dos programas em escolas primárias com ênfase à educação sobre as conseqüências e influências sociais do uso do tabaco e tratamento com base no comportamento, tanto na população de crianças, adolescentes quanto adultos jovens, principalmente quando associados aos substitutos do tabaco, como 0 chicletes de nicotina de $2 \mathrm{mg}$, que sozinhos não mostraram ser efetivos. Relataram que cerca de $2 / 3$ dos cirurgiões-dentistas estavam pessimistas em relação à capacidade que os usuários possuem para mudar seu próprio comportamento. Estudos demonstraram que os cirurgiões-dentistas podem causar um significante 
impacto sobre os usuários, devendo intervir por um caminho similar ao desenvolvido por médicos do Instituto Nacional do Câncer dos EUA, em linhas gerais recomendadas ao seguir os quatro "As" de intervenção: Ask (pergunte), Advise (aconselhe, informe), Assist (ajude) e Arrange Follow-up (acompanhe).

Em 1997, foi sugerido por BENOWITZ7 que informações com relação aos potenciais perigos da nicotina e doenças bucais associadas ao vício do TSF podem ser introduzidas nos programas educacionais para desencorajar o uso.

Além do TSF não ser uma alternativa segura para o cigarro e perigoso para saúde, ele é mortal para STRAFFON; MCG OWAN ${ }^{75}$, em 1997. Jogadores de beisebol, freqüentemente são vistos com tabaco em suas bochechas; seus pais ignoram o perigo, pois muitos acreditam na falsa segurança do TSF, dizendo em relação aos filhos que usam: "Bem, pelo menos eles não fumam". Atualmente, mesmo conhecendo os efeitos carcinogênicos do TSF, o assunto recebe pouca atenção pela saúde pública. De acordo com levantamentos do Departamento Federal de Saúde e Serviços Humanos, de Atlanta, 63\% dos usuários do TSF acreditam que o produto seja uma alternativa ao cigarro, 50\% não acreditam que apresente sérios riscos à saúde, $25 \%$ não sabem que os produtos contêm nicotina e $25 \%$ não sabem que os produtos viciam. D evido à área de predileção onde o TSF é colocado, ele provavelmente é um fator causal de carcinoma bucal. Os autores encorajam os cirurgiões-dentistas a oferecer informações e conselhos a seus pacientes para cessar o uso do TSF, além disso, eles tem oportunidades e responsabilidades. 0 uso de celebridades nacionalmente conhecidas é um importante ingrediente para as campanhas antitabagismo. 
Para avaliar a efetividade de um programa de intervenção para cessação do uso do TSF, MASOUREDIS et al. ${ }^{54}$, em 1997, conduziram na Califórnia um estudo com jogadores de beisebol e futebol de áreas rurais e urbanas em igual número. Foi selecionado um grupo de intervenção onde foram realizados exames bucais, orientações sobre os efeitos maléficos do TSF, exibição de fotos de câncer bucal e desfiguramento facial pelo câncer bucal, e ainda, receberam um guia de auto-ajuda e foram aconselhados a parar o uso pelo cirurgião-dentista e higienista dental, fazendo-se dois telefonemas após a sessão de intervenção para dar suporte. O grupo controle recebeu orientações da higienista em grupos de três ou quatro atletas, mas não foram aconselhados parar 0 uso. Após três meses, as taxas de cessação de uso foram de 24 e 16\% para a intervenção e controle, respectivamente. Os autores afirmaram que os cirurgiões-dentistas têm um papel efetivo na promoção de programas de cessação do uso do TSF.

No Texas, segundo PROKHOROV et al. ${ }^{62}$ em 1998, estima-se que $8 \%$ dos homens adultos sejam usuários, estando a maior prevalência entre as idades de 25 a 34 anos (12,1\%). Em levantamento realizado na Texas School, relataram o uso do TSF em alunos de $1^{0}$ e $2^{\underline{0}}$ grau, com diferença significante do usuário em relação ao gênero, 20,8\% masculino e $2 \%$ feminino, sendo mais comum em homens brancos. Devido aos problemas de saúde bucal ocorrerem mais freqüentemente com o uso prolongado do TSF, o cirurgião-dentista os conhece bem: halitose, alterações nos tecidos moles e duros da boca, leucoplasia, pigmentação, abrasão e desgaste dentário, recessão gengival e destruição do osso periodontal. O TSF equivocadamente é considerado uma alternativa "benigna" ao cigarro, tanto por clínicos quanto pela população em geral. Desde que o uso do TSF seja iniciado tipicamente durante a adolescência, as recomendações de prevenção enfocam primeiramente os jovens, já as de recomendações de suspensão visam tanto jovens como adultos. As estratégias na prevenção ao uso são caracterizadas por seis 
componentes: perguntas, informações, ajuda, organização, adoção e atuação. Salienta-se que o clínico pode exercer um papel fundamental no controle antitabaco, falando para diferentes grupos, atuando na comunidade, envolvendo campanhas e programas de caráter político, escolar, social e que embora muitas dessas estratégias requeiram treinamento e tempo, enfatiza-se que mesmo mínimas intervenções podem ser efetivas no combate ao uso do TSF.

Num estudo com 152 alunos de odontologia, futuros profissionais, acerca de seus conhecimentos sobre as relações entre 0 vício de fumar e suas conseqüências para a saúde bucal, CHAIM; COPPI ${ }^{15}$, em 1998, constataram que $36,8 \%$ e 4,6\% desconheciam os riscos do fumo em relação às doenças periodontais e ao câncer bucal, respectivamente, concluindo sobre a necessidade de uma maior atenção quanto ao vício durante 0 período de formação do aluno, para que programas de promoção de saúde em que estejam introduzidas condutas antitabagistas possam ter resultados.

O tabaco contribui com mais de 450.000 mortes anualmente nos EUA, conforme SEVERSO N ${ }^{70}$ em 1998, representando a causa principal de doenças e mortes evitáveis. Ressalta ainda, dentro da intervenção educacional, a importância de distinguir entre a intervenção clínica, onde as pessoas recebem atenção individual ou em grupo em uma população alvo ou a intervenção em saúde pública que tenta identificar os usuários em um local e independente de sua motivação ou interesse em parar o uso, promove curtas intervenções, com o intuito de aumentar o interesse da pessoa em parar de usar e oferece ajuda. Essas modestas ações geram taxas de suspensão do uso de 5 a 10\%. Esses programas de intervenção visam a área médica, limitando o setor odontológico que poderia incluir os usuários do TSF, cujo uso está associado a doenças bucais, como: câncer bucal, leucoplasias, estomatite nicotínica, recessão gengival, periodontites e alterações nos tecidos 
moles, já que os cirurgiões-dentistas e as higienistas dentais possuem uma oportunidade única de intervenção, dando conselhos diretos para a cessação do uso, através de relatos de lesões bucais para os usuários do TSF, e exibição de breves vídeos de motivação, além de fornecerem material de auto-ajuda, assim os pacientes são encorajados a parar o uso, durante as visitas de rotina que são mais longas que as "típicas" visitas aos médicos.

Preocupados com a realização de programas de motivação para suspender o uso do TSF realizados nos consultórios odontológicos, CAMPBELL; SLETTEN; PETTY ${ }^{13}$, em 1999, verificaram que há uma discrepância entre as respostas dos cirurgiões-dentistas e seus pacientes. Estes autores observaram que um total de 58,5\% dos pacientes entrevistados afirmaram que os cirurgiõesdentistas deveriam oferecer-lhes este tipo de serviço, enquanto $61,5 \%$ dos profissionais disseram que os pacientes não esperam receber este serviço. Nota-se que os pacientes interessados em parar o vício do tabaco, sentem-se mais confortáveis quando recebem essas informações de profissionais de saúde. Estimase que 10 a $20 \%$ da cessação do uso ocorre após os pacientes receberem orientações de profissionais de saúde e apropriada assistência de seus médicos e 18\% após orientações de cirurgiões-dentistas, tornando-se necessária uma melhor comunicação entre cirurgiões-dentistas e seus pacientes.

Em um estudo realizado na Califómia em 1999, WALSH et al. ${ }^{84}$ selecionaram jogadores de futebol e beisebol de várias universidades para determinar a eficácia de um programa de intervenção para cessação do uso de TSF após um ano. 0 grupo de intervenção constava de 171 jogadores e o controle de 189. Eles responderam a um questionário sobre fatores demográficos, características de uso do TSF e motivação para parar o uso. O grupo de intervenção passou por um exame bucal de tecidos moles realizado por um 
cirurgião-dentista, receberam informações para parar 0 uso, viram fotografias de alterações teciduais e desfiguramento facial devido ao câncer bucal de outros usuários de mesma idade, receberam um guia de auto-ajuda e uma sessão de aconselhamento com uma higienista dental, que após um mês telefonava para cada atleta obtendo informações e dando conselhos. O grupo controle recebeu orientações da higienista em grupos de três a cinco indivíduos. Após um ano a prevalência de cessação foi de 35 e 15,9\% para o grupo de intervenção e o controle, respectivamente, o que comprova a efetividade dos programas de intervenção.

O tabaco de mascar e o rapé são as duas principais categorias do TSF. 0 tabaco de mascar contém alto nível de açúcar, podendo ser cariogênico. Baseados nisto, TOMAR; WINN ${ }^{82}$ em 1999, calcularam a média de dentes permanentes cariados e obturados, superfícies coronárias cariadas ou restauradas e superfície radicular cariada e restaurada ou só cariada. Em uma amostra de 14.807 adultos com 18 anos ou mais, 92,9\% eram homens usuários atuais de TSF, sendo que 90,4\% usavam somente o tabaco de mascar, idade média de 40,1 anos e, 90,3\% eram brancos. A média de número de dentes nas quatro categorias estudadas foi maior para os que usavam apenas o tabaco de mascar do que para aqueles que também usavam outras formas de tabaco. Os autores notaram a presença de gengivites associando à higiene bucal como um co-fator para o desenvolvimento de cáries em usuários de TSF, concluindo que o tabaco de mascar pode ser um fator de risco para o desenvolvimento de cáries radiculares e em menor extensão para cáries coronárias, afirmando que cirurgiões-dentistas e outros membros da saúde bucal têm importante papel na redução dos riscos de desenvolvimento de doenças bucais e sistêmicas. 
Os produtos de tabaco continuam sendo acessíveis para menores, para avaliar quais elementos estão associados a essa venda ilegal para menores CLARK et al. ${ }^{22}$ no ano de 2000 analisaram 110062 estabelecimentos de venda nos EUA e Distrito de Columbia, concluindo que a falta de verificação da idade, os mais velhos compram para os menores, vendedores do gênero feminino e menores, o controle aos sábados, tipo de loja (lojas de conveniência, farmácias que vendem vários produtos, postos de gasolina, supermercados) e lojas em áreas rurais são alguns fatores contribuintes para a venda ilegal, sugerindo os autores que o processo de obediência à lei deve ser otimizado.

Para JONES ${ }^{42}$, em 2000, as principais ações contra o uso do TSF são: 1.desenvolvimento e implementação de programas educativos de saúde pública e materiais sobre os riscos envolvendo o uso dos produtos do TSF; 2.inclusão de anúncios da prevenção da saúde sobre todos os produtos do TSF e divulgação desses; 3.autorização para pesquisas sobre os efeitos do uso do TSF.

Conforme relato de BENSON et al. ${ }^{8}$ no ano de 2000 com relação aos cirurgiões-dentistas se envolverem com programas de cessação do uso do TSF, estes não podem ignorar o uso do TSF em tratamentos periodontais pois seria como ignorar cáries quando se faz restaurações, sendo ético integrar este serviço a prática clínica, devendo estar atento ao uso com relação a certos problemas de saúde bucal pois interfere no tratamento e prognóstico. Como membros da sociedade civil ajudando as pessoas pararem com 0 vício estamos fazendo o bem e o uso do tabaco pode levar a reações de dependência que sem ajuda o usuário não consegue parar 0 vício. 
Para STATEMENT ${ }^{73}$ em 2001 a decisão de usar o tabaco é pessoal sendo o resultado de uma complexa interação de fatores que variam de um indivíduo para outro, o mesmo ocorre com a redução do uso. 0 autor define uma estratégia que inclui três pontos: 1.prevenção, sendo a mais importante, ajudar 0 não usuário a não começar com o vício; 2.cessação, ajudar o usuário a parar com 0 vício e prevenir recaídas e a 3.proteção para os não usuários quanto aos efeitos maléficos do tabaco. Algumas barreiras dificultam as ações dos profissionais de saúde para realizar serviços de cessação do uso do tabaco como: falta motivação efetiva quanto a sua própria mudança de comportamento, tempo insuficiente para os aconselhamentos durante o período diário de atendimento, falta de consciência da população sobre os serviços de cessação, frustração dos profissionais com as altas taxas de recaídas. Porém, breves intervenções por um profissional de saúde significa um aumento no índice de cessação, sugerindo o autor: uma colaboração multidisciplinar dos profissionais de saúde para o controle do uso do tabaco, inclusão de treinamento para cessação do uso dentro do currículo de graduação nas várias áreas, divulgação de pesquisas sobre as reduções promovidas pelas estratégias de ações, aumentar a conscientização pública para os programas de ação e retaguarda de suporte.

SAMEK $^{68}$ em 2001 enfatiza que o usuário de tabaco precisa saber mais informações sobre a relação entre uso de tabaco e 0 câncer bucal e doença periodontal, perguntando quem melhor poderia desenvolver esse importante assunto de saúde com o paciente além do cirurgião-dentista.

O consultório odontológico pode ser altamente relevante no contexto do aconselhamento da cessação do uso de tabaco, conforme relato de CAMPBELL et al. ${ }^{12}$ em 2001. Os efeitos bucais do vício aparecem antes que os sistêmicos; homens e adolescentes freqüentam com maior regularidade os consultórios odontológicos 
do que os médicos. Para maior sucesso na intervenção, além do cirurgião-dentista os membros da equipe odontológica devem estar envolvidos no processo: higienistas e auxiliares e um local da recepção deve conter material sobre a cessação do uso. Os usuários de tabaco devem ser identificados, informados sobre os efeitos bucais do tabaco e da necessidade de parar o uso, pergunta-se sobre a intenção de parar, caso haja a vontade aconselhe, ajude, oriente e acompanhe, caso contrário deixe claro que quando a pessoa quiser você estará pronto para ajudá-lo.

\subsection{TSF E DESEMPENHO DOS ATLETAS}

ROBERTSON et al. ${ }^{65}$ em 1995 realizaram estudo a respeito do uso do TSF e como pode afetar o desempenho dos jogadores da maior liga de beisebol dos EUA. Os estudos iniciaram em 1988, com jogadores de sete times profissionais, através de questionário e exame clínico. Devido ao tradicional uso do rapé e do tabaco de mascar estar associado ao esporte e além de ter uma alta prevalência de uso entre os jogadores de beisebol, estes servem de modelo para crianças e adolescentes, que tentam imitar, para parecer com seus ídolos. Foram avaliados os registros de desempenho de 158 jogadores. Não houve diferença entre os jogadores usuários do TSF e os não usuários em relação aos rebatimentos de bola, colocar a bola em campo, correr da base ou arremessar, bem como a atuação psicomotora. No entanto, se o jogador parar de usar durante os jogos ou nos dias anteriores ao jogo, ele é prejudicado pela disfunção cerebral causada pela síndrome da 
abstinência. O uso aumenta significativamente os riscos de lesões na mucosa bucal, além de outras doenças bucais.

Alguns atletas dizem que o TSF os ajuda a jogar melhor, o que sugere que um trabalho de informação deva ser realizado com os atletas sobre os efeitos prejudiciais do uso do TSF e quanto mais cedo começar a educação com crianças e jovens, melhores hábitos eles carregarão para a vida adulta ${ }^{31}$. 


\section{PROPOSIÇÃO}




\section{PROPOSIÇÃO}

Estudar o perfil pessoal e sócio-econômico preliminar do usuário de tabaco sem fumaça e características de seu uso na região de Bauru, Estado de São Paulo, utilizando-se da epidemiologia descritiva. 
4 MATERIAL E MÉTODOS 


\section{MATERIAL E MÉTODOS}

A metodologia baseou-se em entrevistas auxiliadas pelo preenchimento de questionário elaborado especificamente e aplicados no ano de 2000 e está apresentado na FIGURA 1. As entrevistas foram aplicadas e os questionários preenchidos pela pesquisadora e uma aluna da graduação de Odontologia, esta última como parte de trabalho de iniciação científica financiado pelo $\mathrm{CNPq}$ processo número 107328/99-2.

A escolha do local das entrevistas foi determinada por prévio conhecimento de relatos fortuitos e aleatórios de pessoas e profissionais cujos filhos ou amigos tinham contato com o vício do TSF.

As entrevistas foram realizadas com adolescentes e adultos jovens, freqüentadores de ambientes típicos da cultura "country", como laçadores e seus treinadores, organizadores de eventos, "palhaços" e proprietários de locais para treinamento.

Entre os locais e momentos mais utilizados para as entrevistas, escolheuse:

- Parque de exposições agropecuárias Recinto Melo de Morais em Bauru;

- $\quad$ aulas de treinamento de hipismo e laço;

- $\quad$ campeonatos de laço;

- $\quad$ leilões de gado;

- festas de rodeio nas cidades de Bauru e São Manoel; 
- $\quad$ locais privados de treinamento hípico: VS Treinamentos, em Piratininga, e Rancho Canaã, em Bauru;

- escolas agrícolas: Escola Agrícola Fundação Paulo Souza, em Taquarivaí, e ETE Astor Mattos Carvalho em Cabrália Paulista;

- loja especializada em artigos "country": Casa do Cowboy em Bauru.

Logo após a entrevista realizou-se o exame clínico intrabucal com auxílio de espátulas de madeira, utilizando-se de luz solar ou artificial de lanterna comum, dependendo do horário. A acomodação do paciente se fazia com cadeiras e apoios de cabeça improvisados quando possível e de acordo com as melhores possibilidades oferecidas pelo local.

As questões verbalizadas aos entrevistados estão relacionadas na FIG URA 1 que demonstra concomitante conteúdo do questionário aplicado.

Após a entrevista e os exames clínicos, os dados coletados foram armazenados para posterior recuperação e análise. $\mathrm{Na}$ análise das respostas, utilizou-se da estatística descritiva, o que viabilizou a confecção das tabelas e dos gráficos para melhor visualização dos resultados obtidos. 


\begin{tabular}{|l|}
\hline Nome: \\
Gênero: \\
Idade: \\
Raça: \\
Escolaridade: \\
\hline Usuário ou não: \\
Se não, já foi usuário ? \\
Já experimentou ? \\
Por que não se tornou usuário ? \\
\hline Usuário: \\
Quando começou a usar? \\
Por que começou ? \\
Q uando usa ? (só no rodeio ou todo dia?) \\
Quantas vezes ao dia ? \\
Quanto tempo o TSF permanece na boca? \\
Qual a marca que usa? \\
Que tipo ? (pó, saquinho, ...) \\
Quanto custa a latinha? \\
Seus pais sabem que é usuário ? \\
Se sim, eles também usam ? \\
Conhece mais alguém que usa ? (irmão, namorada.....) \\
\hline Exame clínico: \\
Há lesões na boca ? Q ual o diagnóstico? \\
D escrição da lesão: \\
\hline
\end{tabular}

\begin{tabular}{c}
\hline Data:.../ .../ ... \\
Questionário aplicado por ... \\
\hline
\end{tabular}

FIGURA 1- Questionário utilizado para entrevistas e exames intra-bucais aplicado aos usuários de TSF na região de Bauru, Estado de São Paulo 
5 RESULTADOS 


\section{RESULTADOS}

Foram realizadas 129 entrevistas: 123 do gênero masculino e apenas seis do gênero feminino (FIG URA 2). As idades dos usuários variaram de 10 a 30 anos e foram agrupadas em três faixas etárias (FIGURA 3). Predominantemente os usuários de tabaco entrevistados eram brancos 87 ou 67,44\%, sendo 35 ou 27,13\% da cor autodenominada parda ou morena e apenas sete ou 5,43\% negros (FIGURA $4)$.

Entre as características do uso do tabaco sem fumaça nos entrevistados destacou-se que 60 pessoas (46,51\%) eram usuárias entre um a três anos, um período considerável que ultrapassa os períodos adaptativos de novos condutas. Em 19 pessoas (14,73\%) o vício durava entre quatro a seis anos, em outras dez $(7,75 \%)$ transcorreram sete a dez anos de uso. Apenas 8,53\% ou 11 pessoas adquiriram o vício há menos de um ano (FIGURA 5).

O tempo de permanência do tabaco sem fumaça na boca a cada nova inserção, na maioria das pessoas, variou entre 5 a 30 minutos e 30 a 60 minutos respectivamente em 46 (35,66\%) e 27 pessoas (20,93\%), como revela a FIG URA 6. Em quatro pessoas, o material permanecia na boca por cinco horas ou mais. Em 46 casos, 0 usuário não tinha idéia do tempo de permanência do tabaco sem fumaça na boca. 


\begin{tabular}{c|c|c}
\hline Gênero & Número & $\%$ \\
\hline masculino & 123 & 95,35 \\
\hline feminino & 6 & 4,65 \\
\hline TOTAL & 129 & 100 \\
\hline
\end{tabular}

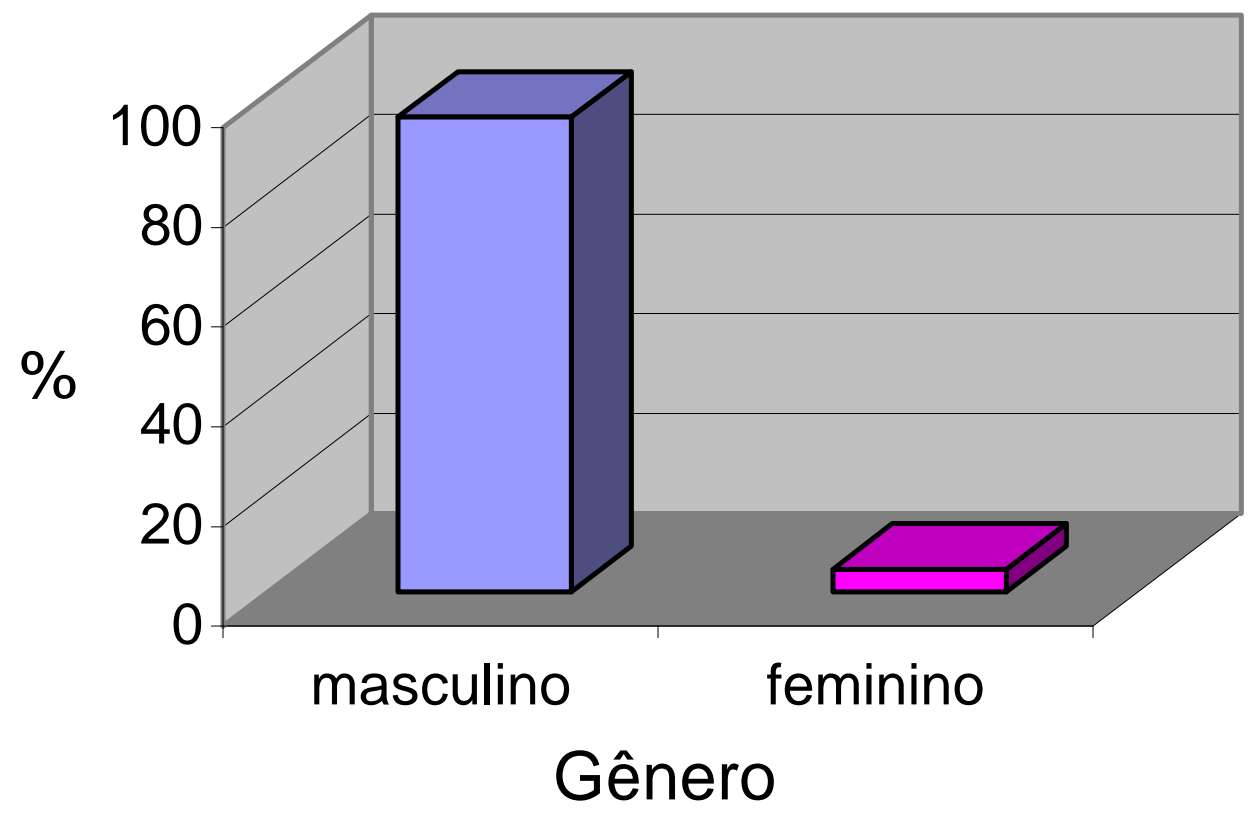

FIGURA 2 - Tabela e gráfico referente ao número de usuários de TSF na região de Bauru, Estado de São Paulo, distribuídos em função do gênero 


\begin{tabular}{c|c|c}
\hline $\begin{array}{c}\text { Faixa etária } \\
\text { anos }\end{array}$ & Número & $\%$ \\
\hline $10-14$ & 17 & 13,18 \\
\hline $15-19$ & 87 & 67,44 \\
\hline $20-30$ & 25 & 19,38 \\
\hline TOTAL & 129 & 100 \\
\hline
\end{tabular}

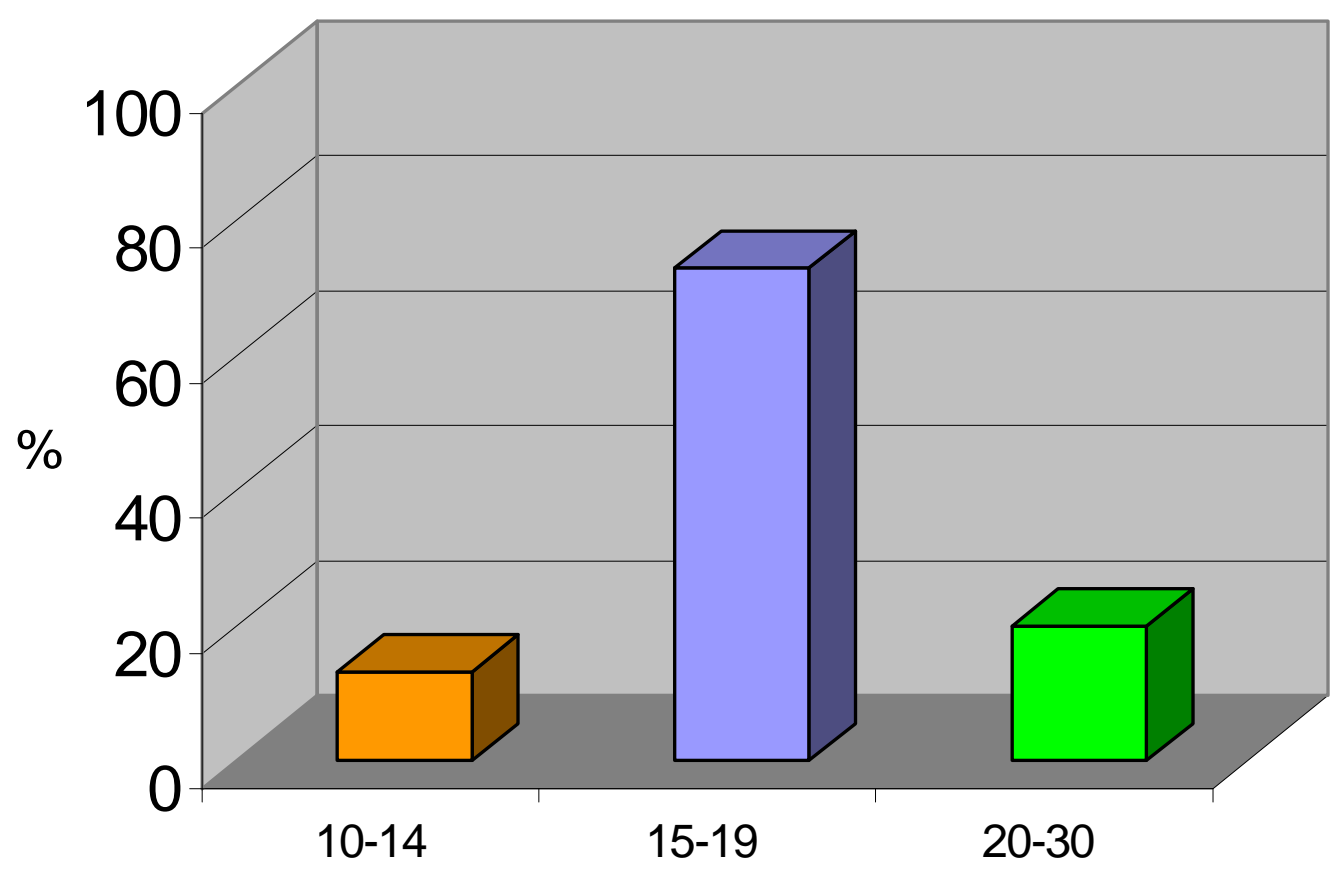

Faixa etária

FIGURA 3 - Tabela e gráfico referente às faixas etárias dos usuários de TSF na região de Bauru, Estado de São Paulo 


\begin{tabular}{c|c|c}
\hline Grupo racial & Número & $\%$ \\
\hline branco & 87 & 67,44 \\
\hline pardo & 35 & 27,13 \\
\hline negro & 7 & 5,43 \\
\hline TOTAL & 129 & 100 \\
\hline
\end{tabular}

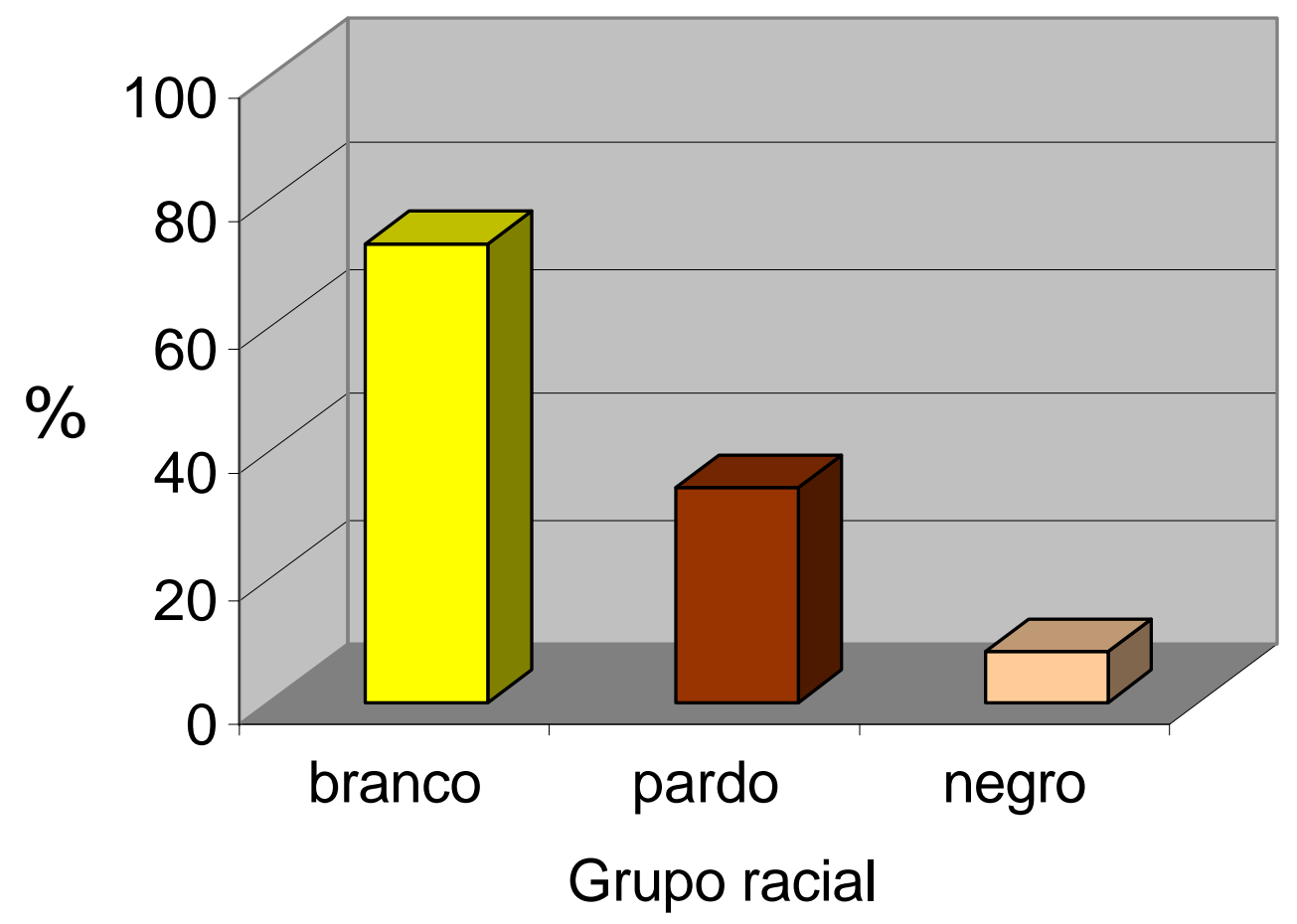

FIGURA 4 - Tabela e gráfico referente ao grupo racial dos usuários de TSF na região de Bauru, Estado de São Paulo 


\begin{tabular}{c|c|c}
\hline Tempo em anos & Número & $\%$ \\
\hline - de 1 & 11 & 8,53 \\
\hline de 1 a 3 & 60 & 46,51 \\
\hline de 4 a 6 & 19 & 14,73 \\
\hline de 7 a 10 & 10 & 7,75 \\
\hline não sabe & 29 & 22,48 \\
\hline TOTAL & 129 & 100 \\
\hline
\end{tabular}

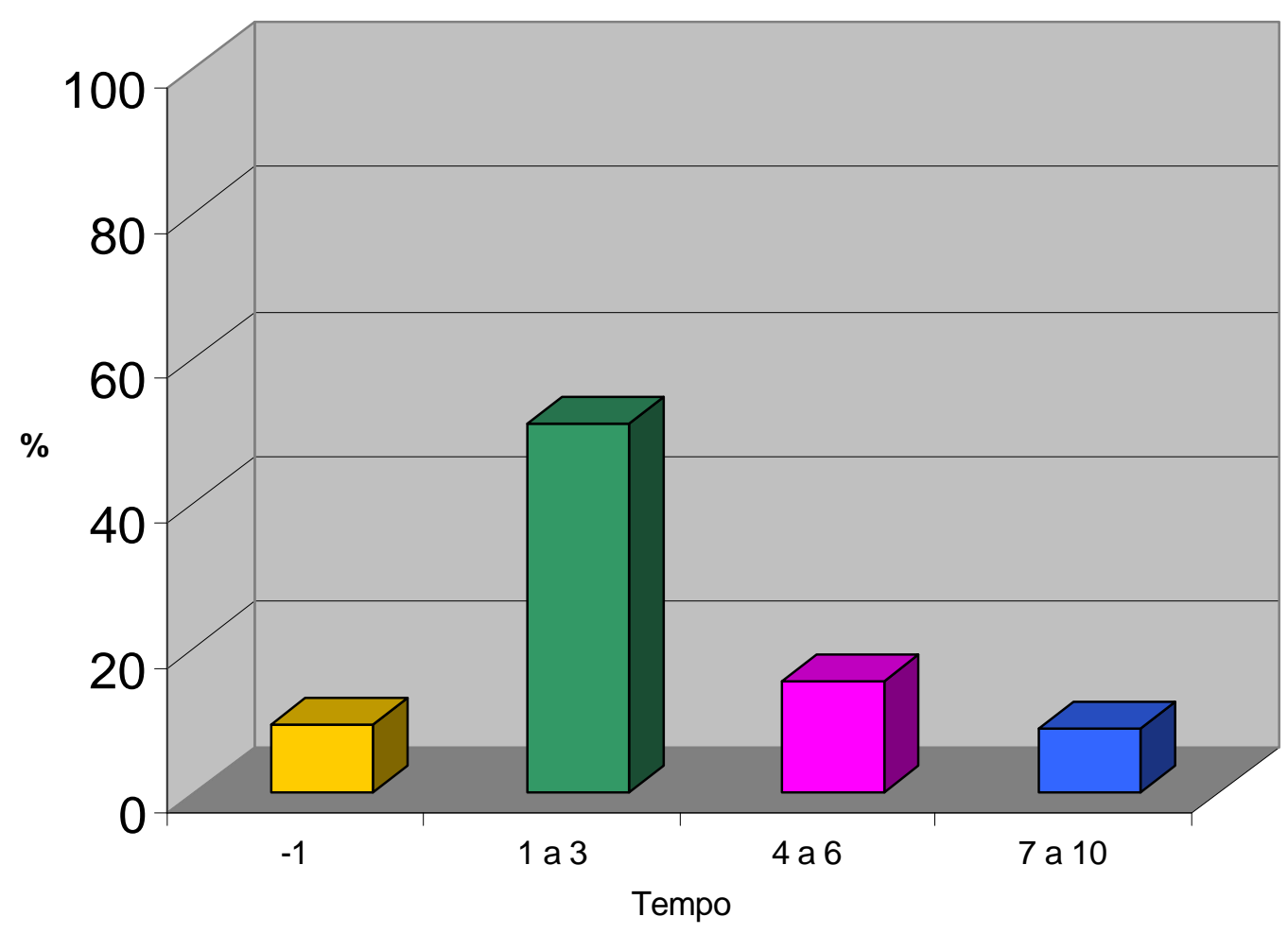

FIGURA 5 - Tabela e gráfico referente à distribuição dos usuários de TSF na região de Bauru, Estado de São Paulo, quanto aos anos de uso 


\begin{tabular}{c|c|c}
\hline Tempo & Número & $\%$ \\
\hline 5 a $30 \mathrm{~m}$ & 46 & 35,66 \\
\hline 30 a $60 \mathrm{~m}$ & 27 & 20,93 \\
\hline 2 a $4 \mathrm{~h}$ & 6 & 4,65 \\
\hline $5 \mathrm{~h}$ & 4 & 3,10 \\
\hline não sabe & 46 & 35,66 \\
\hline TOTAL & 129 & 100 \\
\hline
\end{tabular}

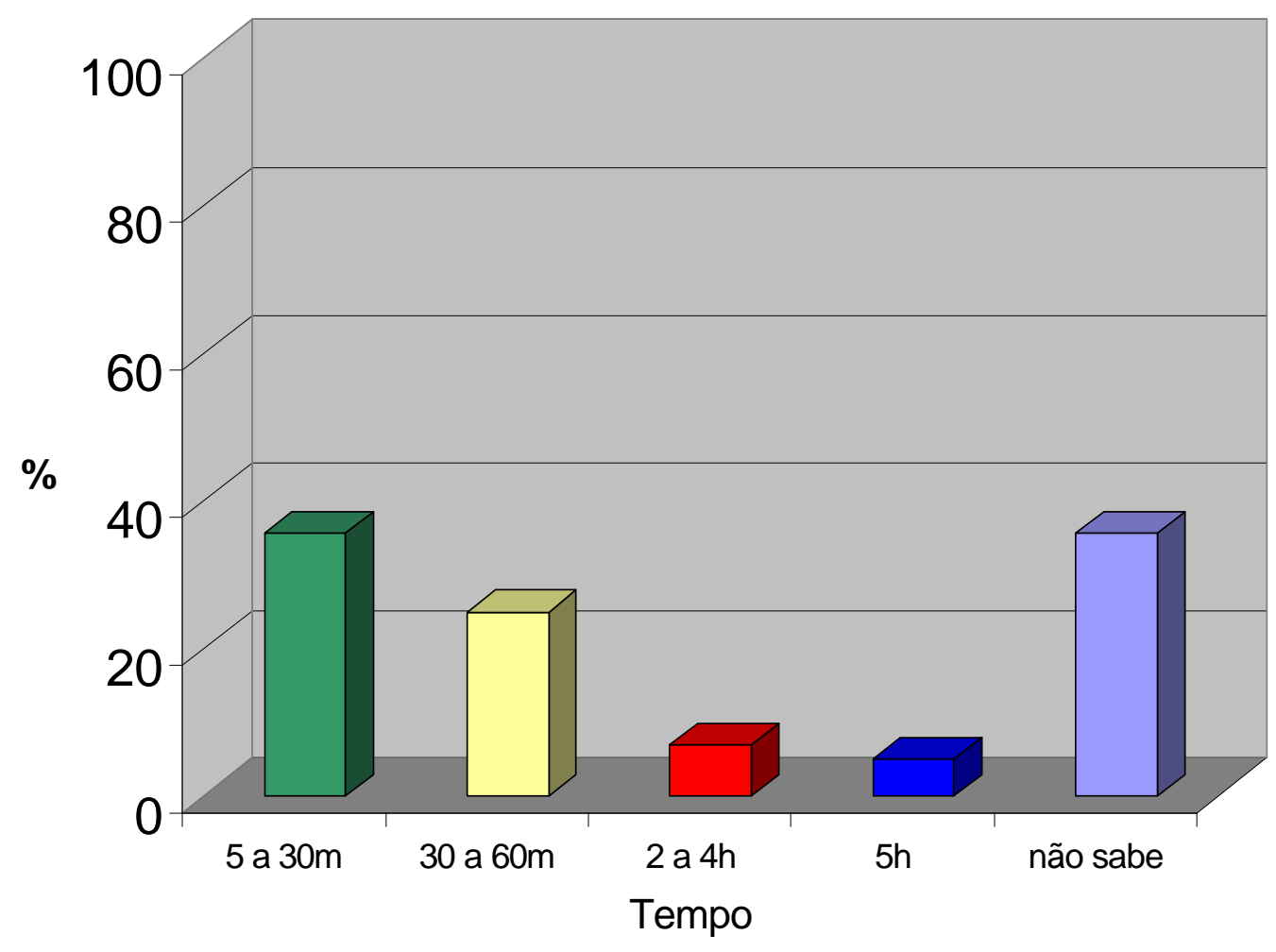

FIGURA 6 - Tabela e gráfico referente à distribuição dos usuários de TSF na região de Bauru, Estado de São Paulo, quanto ao tempo de permanência do material na boca 
As alterações clínicas detectadas nos exames clínicos de 49 ou 37,98\% dos usuários de TSF entrevistados revelaram que a recessão gengival estava presente em 25 ou 19,38\% usuários, as leucoplasias em 14 ou 10,85\% e a pigmentação dentária em 10 ou 7,75\% (FIG URA 7).

O utros sintomas ou sinais mencionados foram gengivites, pigmentações gengivais, depressões no vestíbulo onde o tabaco era depositado, placa dentobacteriana e cálculo dentário.

O local de acomodação do material na boca também foi questionado e 0 vestíbulo da boca na sua parte inferior apresentou como a região mais freqüentemente escolhida pelo usuário do TSF em 79,84\% dos casos ou 103 pessoas. Em seguida, apresentaram-se 21 ou 16,28\% na mucosa jugal e em cinco casos, ambos os locais eram utilizados para a inserção e descanso do material (FIGURA 8).

No uso do TSF, algumas pessoas mencionam cuidados "especiais" para a prática do vício como:

- "não engolir a saliva, pois causa vômito, tontura"

- "não engolir o TSF porque dá diarréia"

- "jogar a porção quando acaba o gosto como se faz com chicletes"

- "o de sachê é para quem está começando, para não engolir o pó"

- "se o TSF ficar muito tempo no mesmo local a mucosa fica áspera"

- "se colocar muito chega a comer a boca"

Quanto às características dos produtos comerciais, a marca mais consumida pelos usuários foi a Copenhagen (56,58\%), seguida pela Skoal $(27,13 \%)$. A formulação caseira $(17,82 \%)$ e o produto popular conhecido como Juriti $(12,40 \%)$ foram freqüentemente citados como revela a FIG URA 9.

Na formulação caseira do TSF, resgatou-se as seguintes receitas: 
- "uma mistura de Juriti, mel, whisky, conhaque, achocolatado tipo Nescau e açúcar"

- "uma mistura de Juriti, conhaque, mel, caramelo tipo Hall's, chocolate em pó e pinga. A mistura é levada ao fogo para apurar, deixa descansar mais ou menos 15 dias e está pronta"

- "mistura Juriti com caramelo tipo Hall's de menta moído"

D epois de prontas estas mistura são colocadas nos recipientes do TSF importado.

A marca comercial nacional e popular Juriti consiste apenas de folhas de tabaco moída ao contrário dos produtos importados.

O fumo de corda foi mencionado como uma forma de tabaco para mascar por apenas um usuário, sendo mais consumido para confecção de cigarros de palha.

Conhecimento familiar do vício do tabaco sem fumaça foi predominante entre os usuários entrevistados, detectando-se que em $80,62 \%$ os pais sabiam a respeito desta prática pelo filho (FIGURA 13).

Algumas observações e razões curiosas para o vício foram mencionadas como motivos para a iniciação do vício, destacando-se:

- "experimentei porque meu namorado usava"

- - "é gostoso"

- -"é da hora"

- -"meu avô usava e tem os dentes bons"

- -"todo mundo usa"

- - "faz parte da vida de peão" 
- -"porque é sertanejo"

- -"via os outros usando, dava vontade"

Interessante salientar que apenas oito ou 6,2\% de pais ou familiares dos usuários entrevistados também tinham o vício do TSF (FIG URA 14).

O utro aspecto a destacar entre os dados coletados está a escolaridade do usuário, predominantemente de grau médio como foi detectado em 88 pessoas ou $68,22 \%$ e escolaridade fundamental em 33 ou 25,58\%. Em apenas oito casos ou $6,2 \%$ a escolaridade era de nível superior (FIG URA 15).

Além da escolaridade, percebeu-se que a formação de grupos de comportamentos ou práticas semelhantes levavam os não iniciados no vício a praticarem para se integrarem ao grupo, cedendo à influência de amigos como foi descrito por 76 pessoas entrevistadas ou 58,91\% dos usuários. A curiosidade foi motivo de iniciação em 48 casos ou 37,21\%. Apenas cinco pessoas disseram ter-se iniciado com o objetivo de parar de fumar (FIG URA 16). 


\begin{tabular}{c|c|c}
\hline Alteração & Número & $\%$ \\
\hline recessão gengival & 25 & 19,38 \\
\hline leucoplasia & 14 & 10,85 \\
\hline $\begin{array}{c}\text { pigmentação } \\
\text { dentária }\end{array}$ & 10 & 7,75 \\
\hline TOTAL & 49 & 37,98 \\
\hline
\end{tabular}

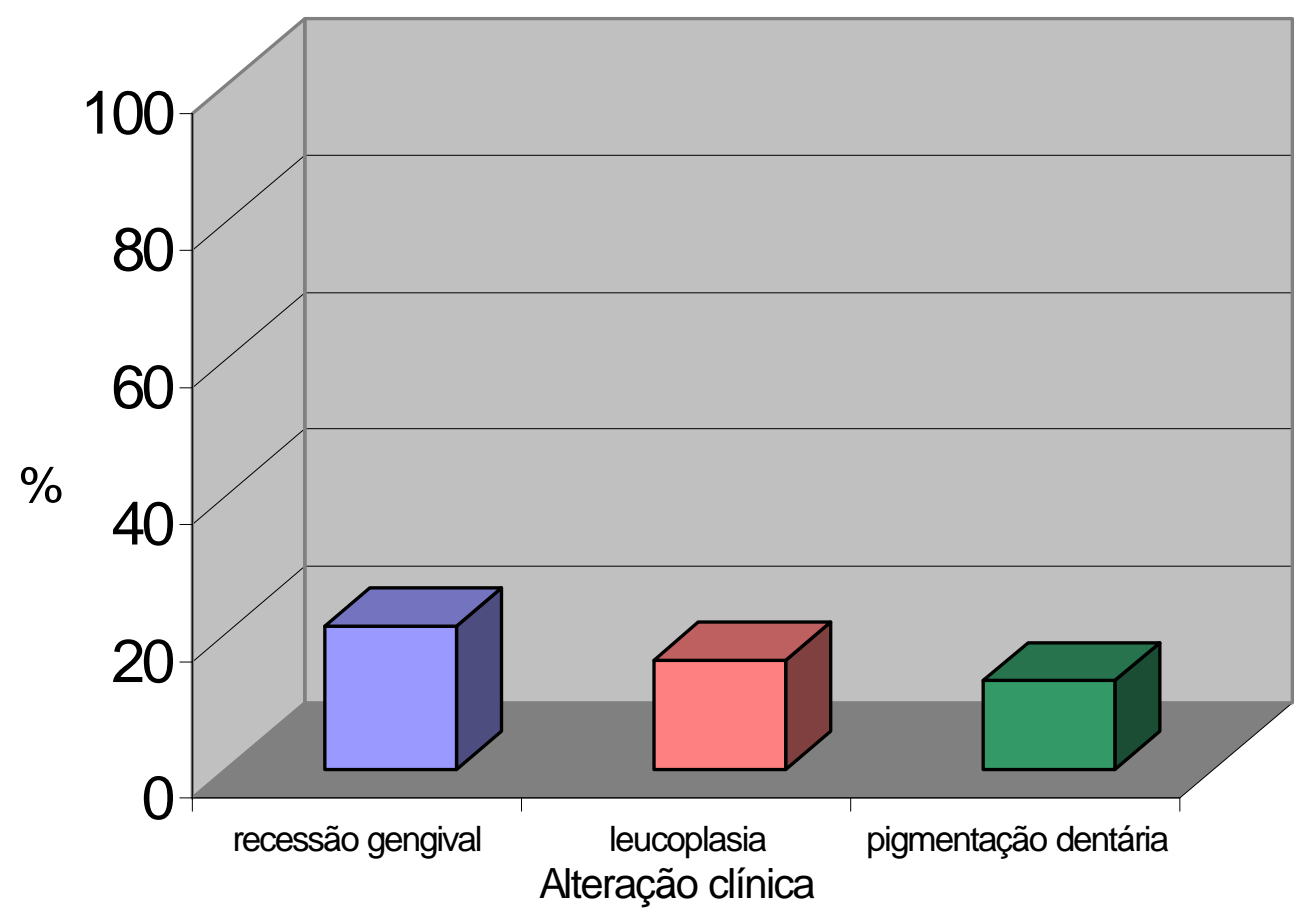

FIGURA 7 - Tabela e gráfico referente à distribuição dos usuários de TSF na região de Bauru, Estado de São Paulo, quanto ao tipo de alterações clínicas encontradas na mucosa bucal 


\begin{tabular}{c|c|c}
\hline Local & Número & $\%$ \\
\hline vestíbulo inferior & 103 & 79,84 \\
\hline mucosa jugal & 21 & 16,28 \\
\hline ambos & 5 & 3,88 \\
\hline TOTAL & 129 & 100 \\
\hline
\end{tabular}

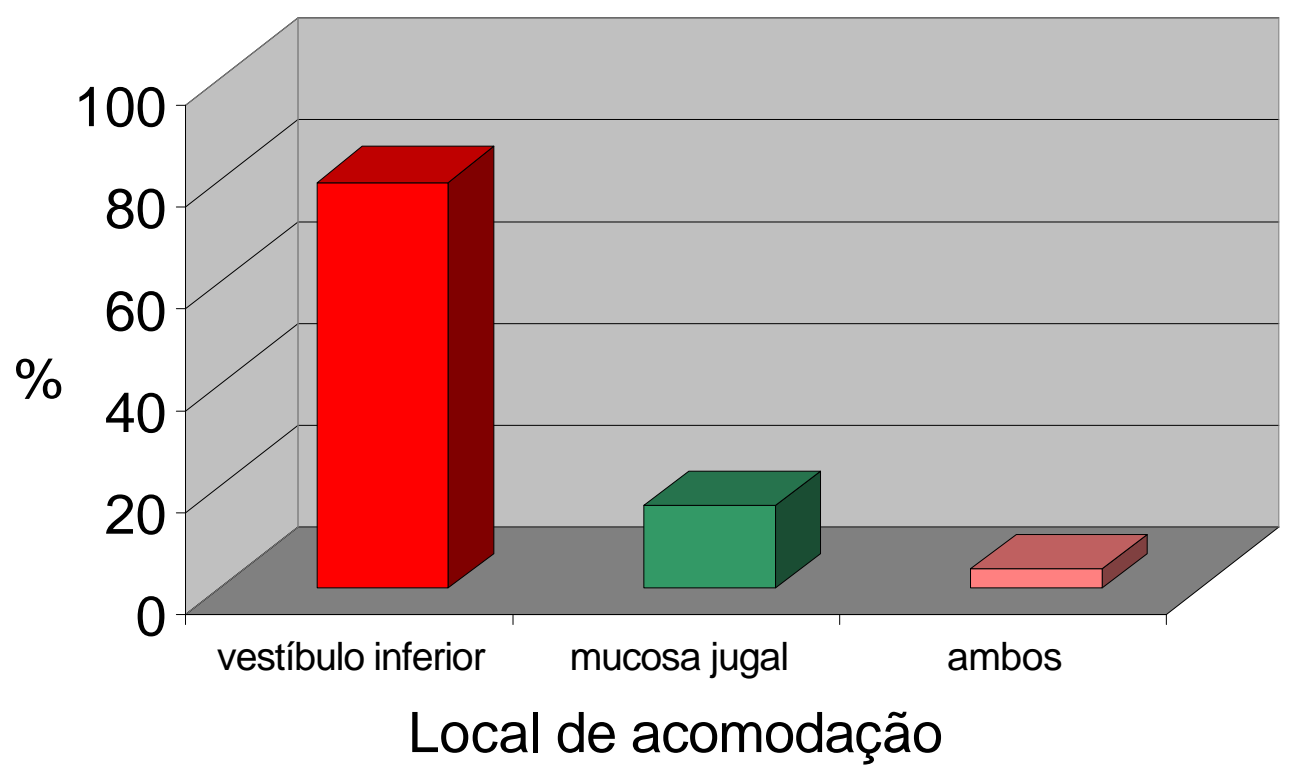

FIGURA 8 - Tabela e gráfico referente à distribuição dos usuários de TSF na região de Bauru, Estado de São Paulo, quanto ao local de acomodação do TSF 


\begin{tabular}{c|c|c}
\hline Marca & Número & $\%$ \\
\hline Copenhagen & 73 & 56,58 \\
\hline Skoal & 35 & 27,13 \\
\hline Caseiro & 23 & 17,82 \\
\hline Juriti & 16 & 12,40 \\
\hline Red Man & 16 & 12,40 \\
\hline Lancaster & 14 & 10,85 \\
\hline Qualquer marca & 11 & 8,52 \\
\hline Bandite & 2 & 1,55 \\
\hline Chanatoga & 2 & 1,55 \\
\hline Fumo de corda & 1 & 0,77 \\
\hline Clássico & 1 & 0,77
\end{tabular}

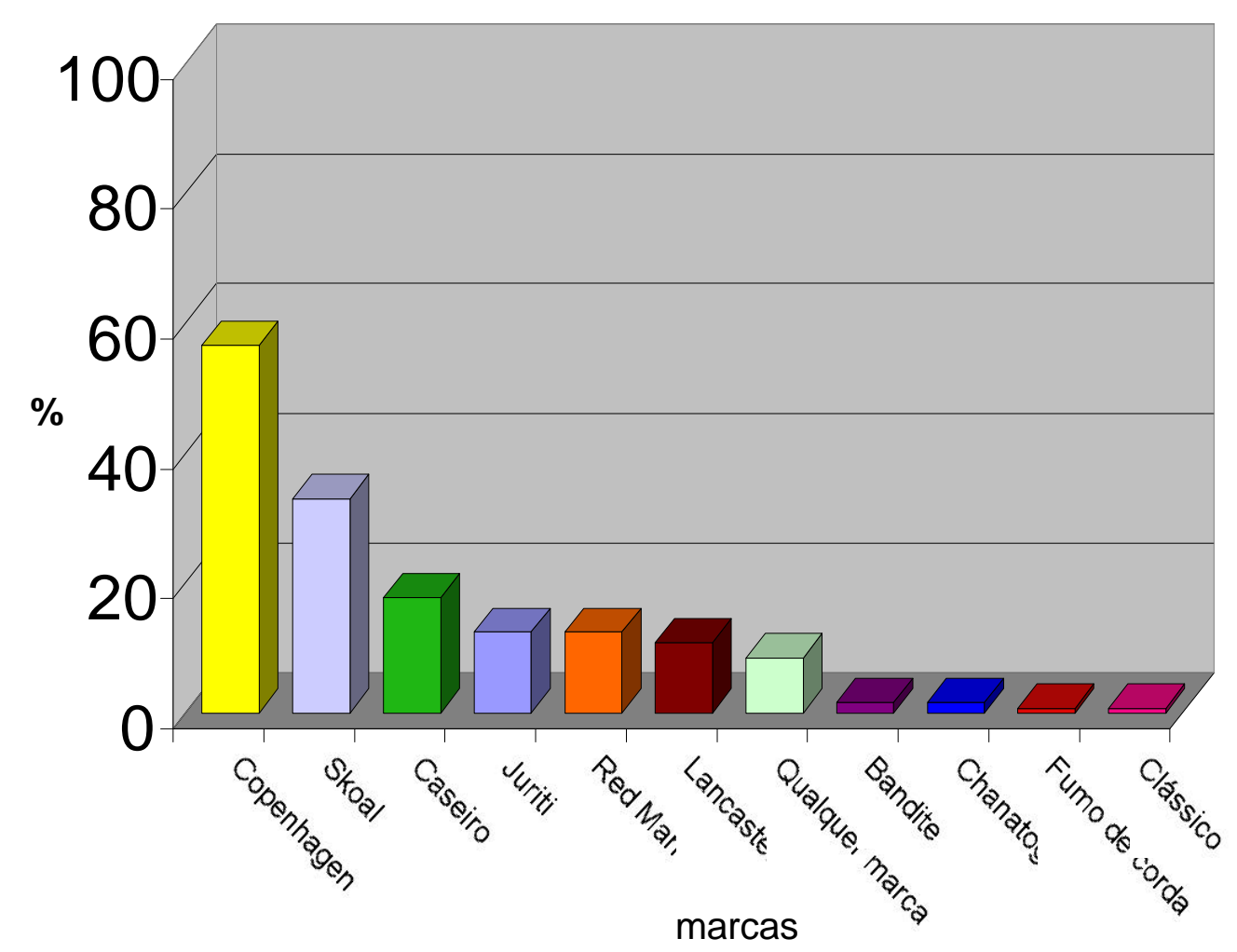

FIGURA 9 - Tabela e gráfico referente à distribuição dos usuários de TSF na região de Bauru, Estado de São Paulo, com relação a marca comercial do TSF consumida 


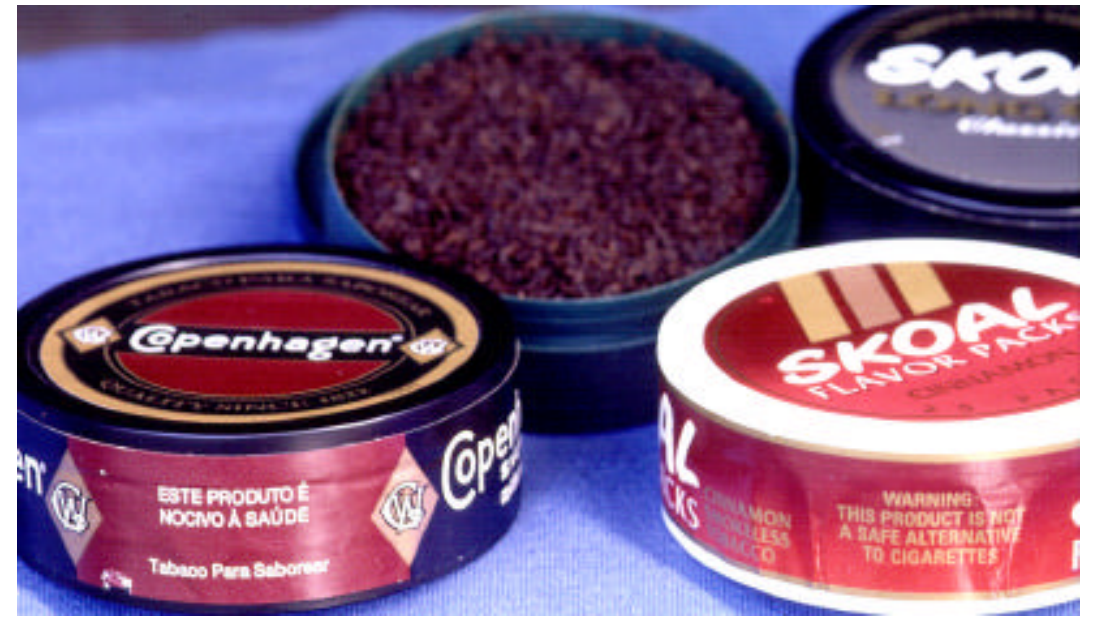

Figura 10 - TSF em "latinhas" embaladas com marcas comercias mais conhecidas entre os usuários contactados durante a realização do trabalho

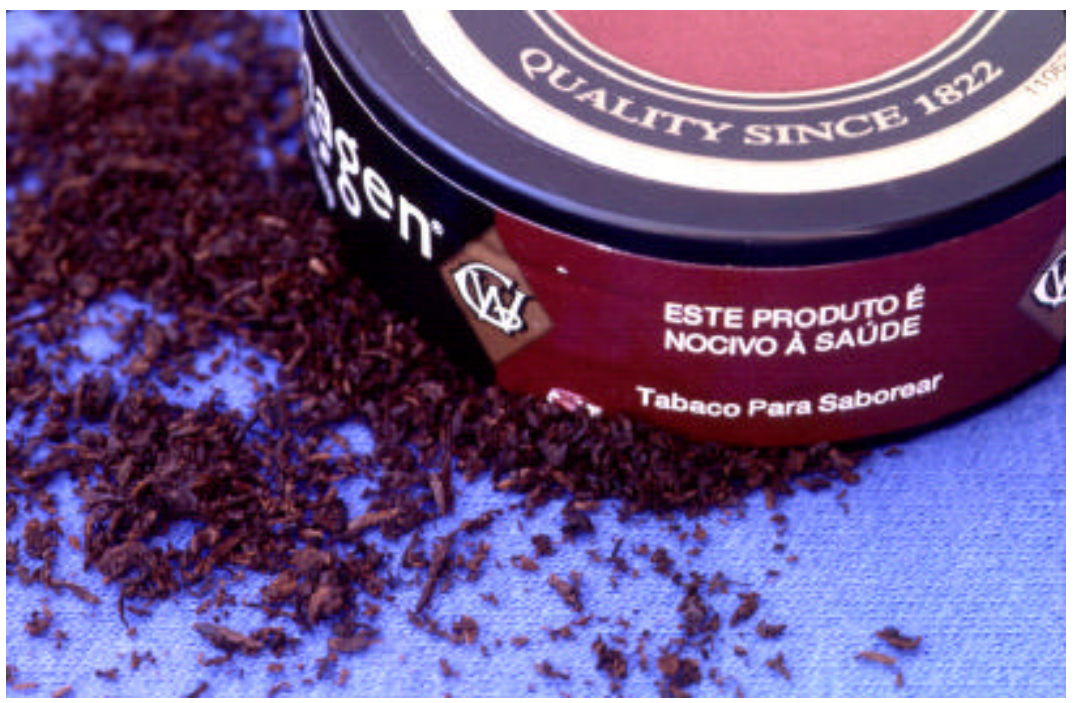

Figura 11 - Aspecto do TSF preparado para o consumo em forma de pequeninos fragmentos, úmidos, a serem posteriormente colocados sobre a mucosa bucal 


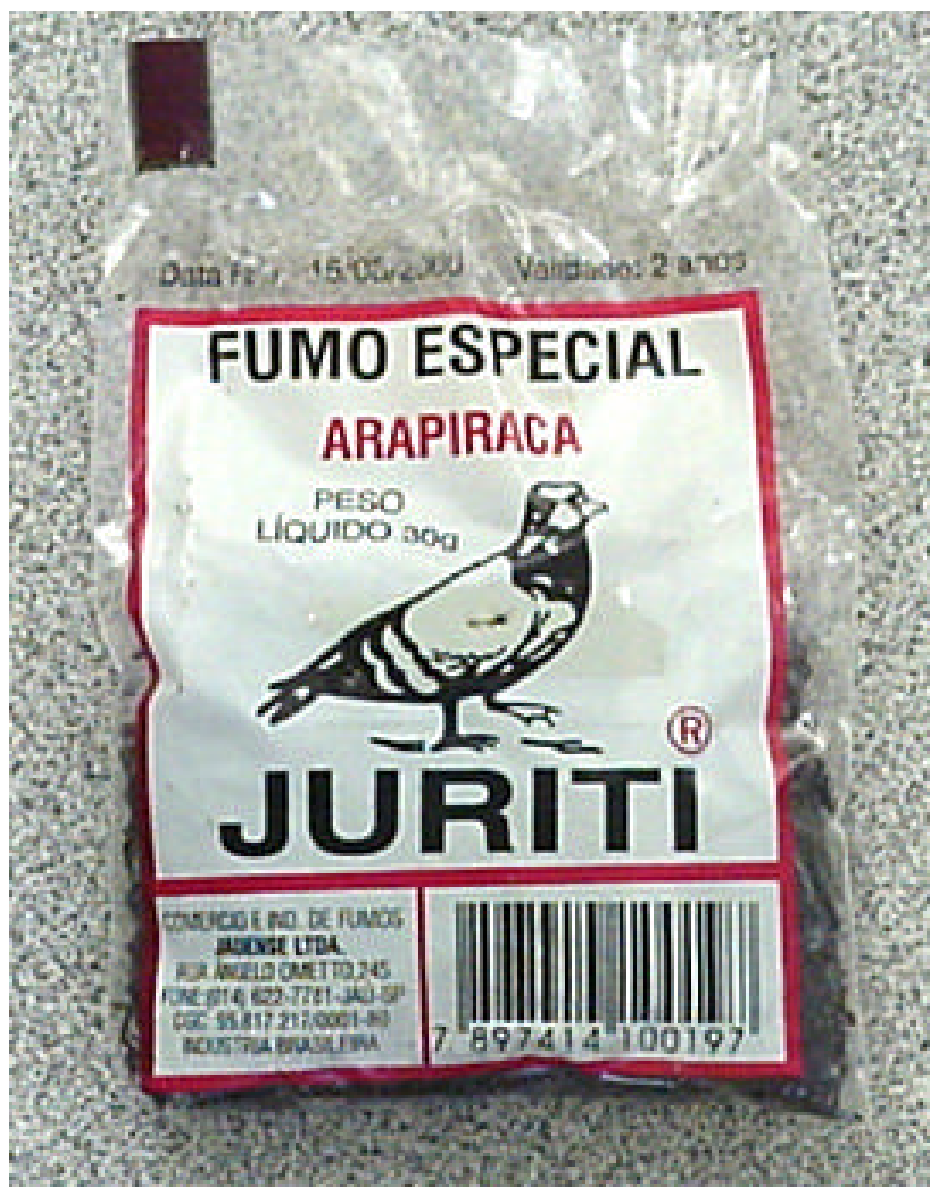

Figura 12 - TSF de fabricação nacional com marca comercial muito conhecida entre os usuários contactados durante o trabalho 


\begin{tabular}{c|c|c}
\hline Uso conhecido & Número & $\%$ \\
\hline sim & 104 & 80,62 \\
\hline não & 25 & 19,38 \\
\hline TOTAL & 129 & 100 \\
\hline
\end{tabular}

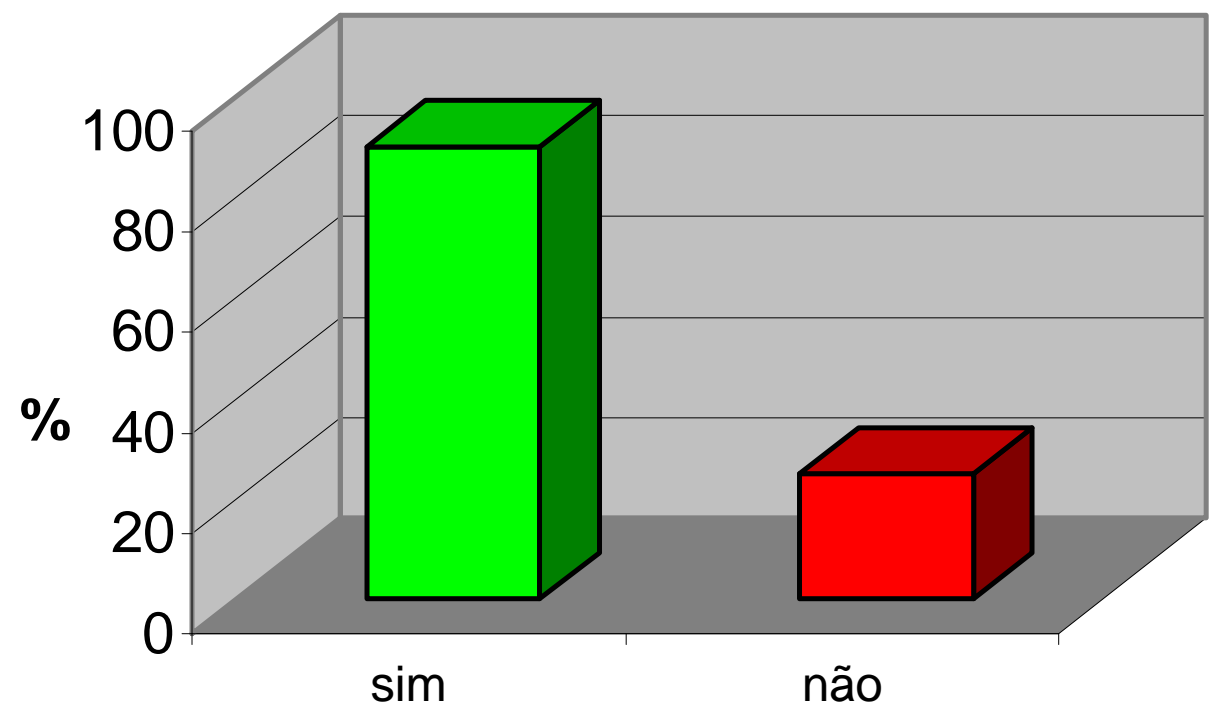

Uso conhecido

FIGURA 13 - Tabela e gráfico referente à distribuição dos usuários de TSF na região de Bauru, Estado de São Paulo, quanto ao conhecimento do vício pelos pais 


\begin{tabular}{c|c|c}
\hline Pais ou familiares & Número & $\%$ \\
\hline usuários & 8 & 6,2 \\
\hline não usuários & 121 & 93,8 \\
\hline TOTAL & 129 & 100 \\
\hline
\end{tabular}

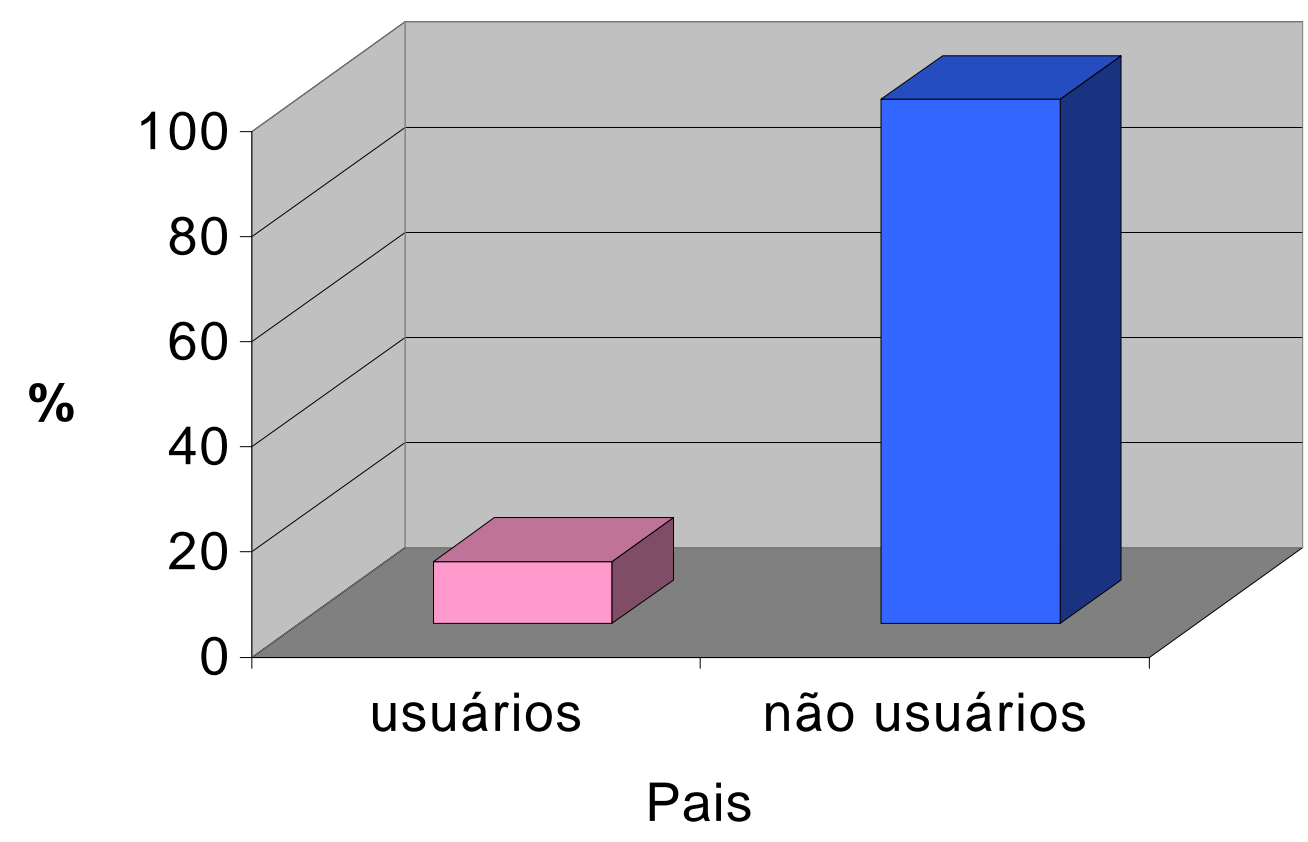

FIGURA 14 - Tabela e gráfico referente à distribuição dos usuários de TSF na região de Bauru, Estado de São Paulo, quanto a ocorrência de pais ou familiares usuários 


\begin{tabular}{c|c|c}
\hline Ensino & Número & $\%$ \\
\hline fundamental & 33 & 25,58 \\
\hline médio & 88 & 68,22 \\
\hline superior & 8 & 6,20 \\
\hline TOTAL & 129 & 100 \\
\hline
\end{tabular}

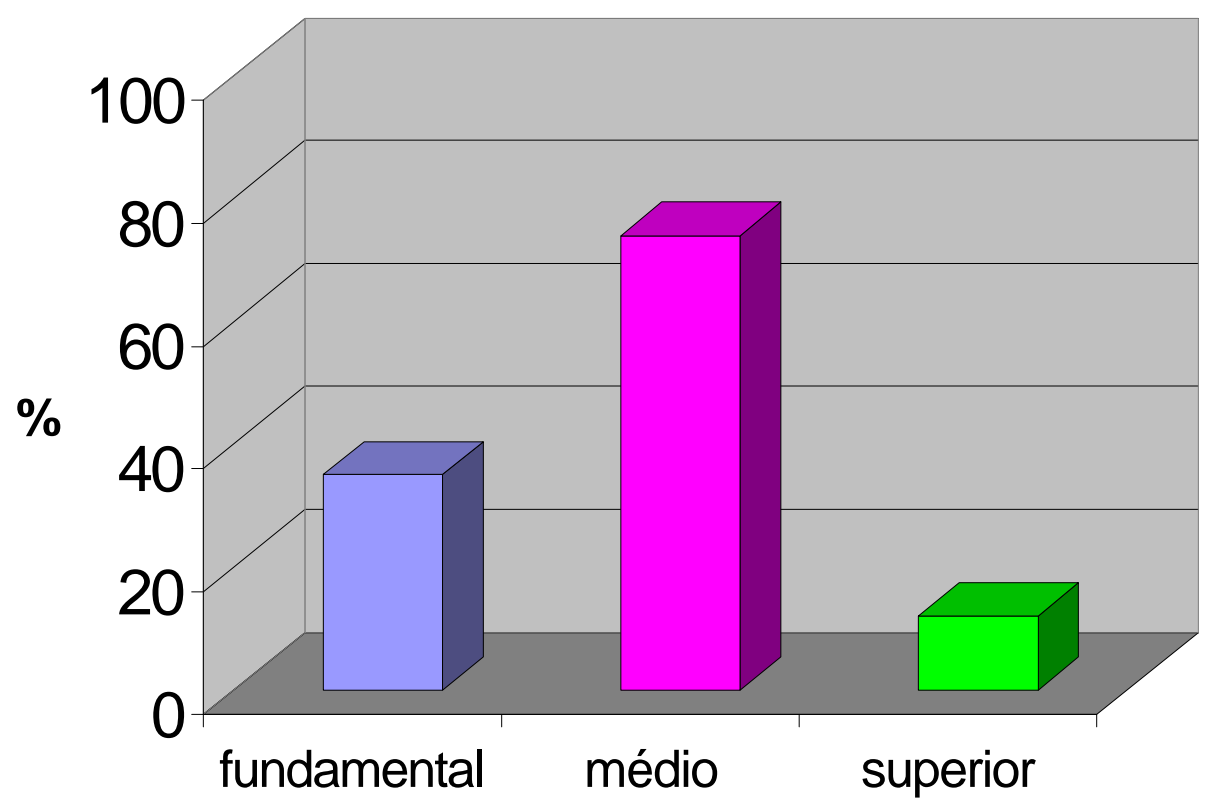

Escolaridade

FIGURA 15 - Tabela e gráfico referente à distribuição dos usuários de TSF na região de Bauru, Estado de São Paulo, quanto a escolaridade dos usuários 


\begin{tabular}{c|c|c}
\hline Motivo & Número & $\%$ \\
\hline influência & 76 & 58,91 \\
\hline curiosidade & 48 & 37,21 \\
\hline parar de fumar & 5 & 3,88 \\
\hline TOTAL & 129 & 100 \\
\hline
\end{tabular}

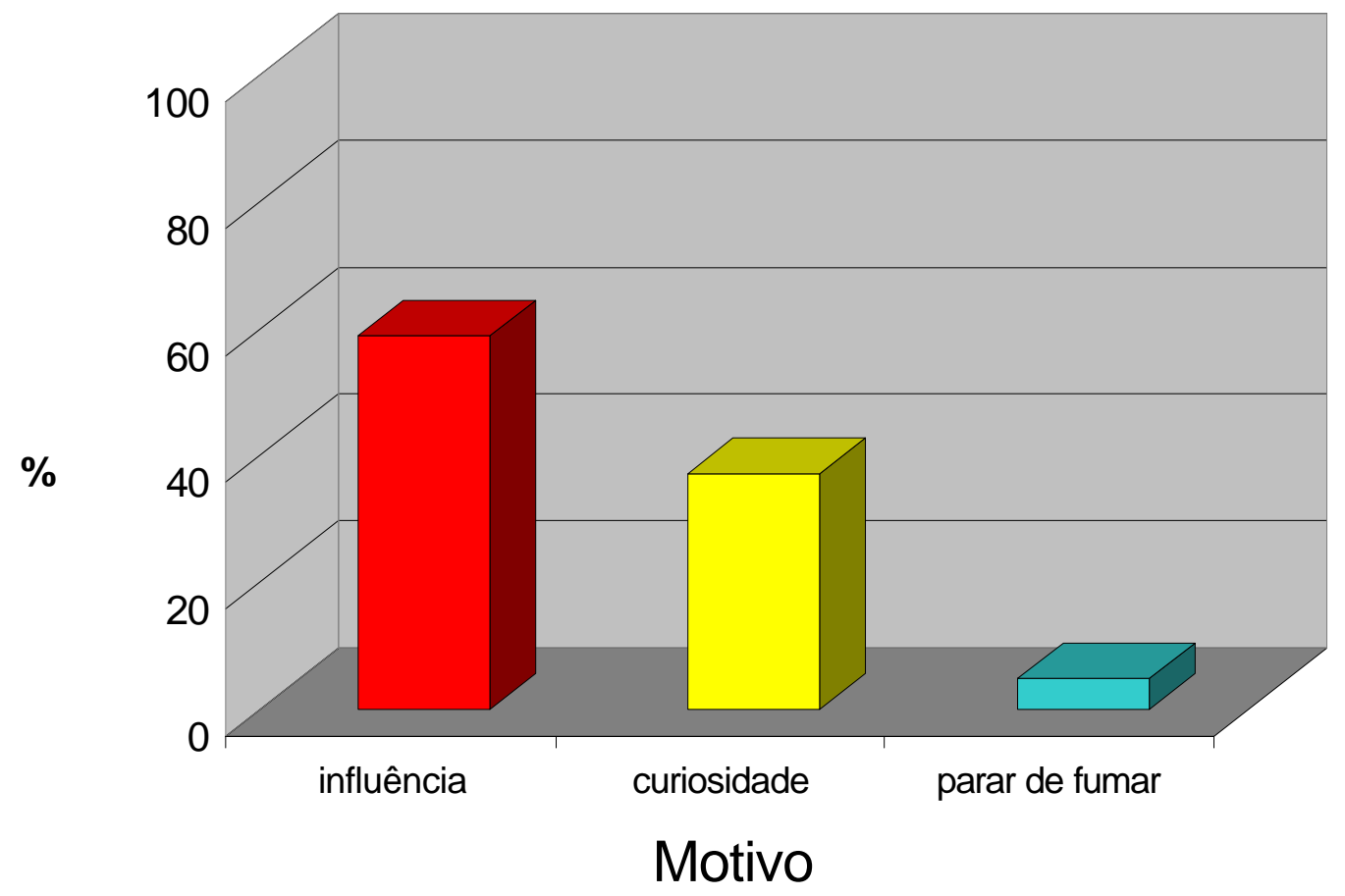

FIGURA 16 - Tabela e gráfico referente à distribuição dos usuários de TSF na região de Bauru, Estado de São Paulo, quanto ao motivo de início do uso 
6 DISCUSSÃo 


\section{DISCUSSÃO}

A concepção desta dissertação se fez ao questionarmos alguns aspectos do assunto durante o curso do Prof. Dr. Bernard Levy, da D ental School of Baltimore, Maryland, USA, sobre "Leucoplasia em crianças" abordando o uso do TSF e suas implicações e desenvolvido na Disciplina de Patologia da FOB-USP. Na época, algumas abordagens foram feitas sobre o uso do TSF no Brasil:

- Serão estes produtos comercializados legalmente?

- Como esses produtos são vendidos no país?

- Onde poderiam ser vendidos?

- Será que existem usuários em nosso meio?

- Qual o perfil destes usuários?

- Onde encontrá-los?

Enfim, vários questionamentos surgiram até que um grupo de alunas da graduação em programa de iniciação científica foi a campo visitando casas de artigos "country" e constatou-se a presença desses produtos para venda. Segundo relato dos vendedores, o consumo era grande por parte de jovens e adultos freqüentadores de ambientes hípicos e rodeios. Apesar do ar amistoso do interesse das alunas, despertou-se o medo da propaganda contrária ao uso do TSF nos proprietários das lojas e estas não mais eram bem recebidas, inclusive em uma das vezes, fechando a loja para que não entrassem. 
A partir de convite, ao realizar-se palestra para pais de crianças e adolescentes que praticavam hipismo, prova de tambores e de laço, confirmou-se 0 uso do TSF por relato dos próprios pais. Em nossos resultados, $80,62 \%$ dos pais tinham pleno conhecimento do vício por parte dos filhos.

A falta de conhecimento da sociedade com o problema, mesmo por parte dos cirurgiões-dentistas, pode ser confirmada durante palestras sobre câncer bucal. Quando o palestrante menciona 0 uso do TSF como um fator para 0 desenvolvimento do câncer bucal, a maioria se mostra bastante surpresa com a existência e o uso do TSF.

Desta forma, concebeu-se este trabalho, inicialmente objetivando procurar usuários do TSF. Uma vez identificados os locais onde mais provavelmente encontraríamos os usuários, propusemos o delineamento do perfil desses usuários através da epidemiologia descritiva na busca de resposta para os fatores relativos às pessoas ${ }^{6}$ :

Q uem foi atingido pelo fenômeno?

Neste item procuramos nos basear em variáveis como idade, gênero, grupo etário, ocupação e condição sócio-econômica.

Esta metodologia mostrou-se pertinente visto que em nosso meio não há relatos a esse respeito; se faz necessário estabelecer um perfil preliminar do usuário através de questionário específico. A pesquisa descritiva pode aparecer sob diversas formas, por exemplo: pesquisa de motivação, pesquisa para análise de trabalho, pesquisa documental, pesquisa histórica, no nosso caso usamos a pesquisa de opinião ou de atitude e de campo onde procuramos saber atitudes, pontos de vista e preferências das pessoas a respeito de algum assunto, realizando-se a coleta de dados onde o fato ou fenômeno ocorre.

O questionário foi elaborado a partir de nossas dúvidas, ou seja, o que queríamos saber: quem usava, qual a sua idade, homens, mulheres, onde usavam, 
com qual freqüência, por que usavam, onde conheceram esse vício, se era fácil comprar e outros questionamentos.

O grande problema desse tipo de metodologia está no fato das pessoas responderem ao questionário de forma voluntária, a resposta depende do entrevistado, não podemos comprovar a veracidade da resposta como em uma pesquisa de laboratório, na qual o resultado se faz por mensurações precisas.

As dificuldades logísticas foram ditadas pelos locais onde as entrevistas foram realizadas como espaços de treinamento afastados da cidade e festas de rodeios noturnos. Outro aspecto que dificultava era 0 acesso às pessoas; eram abordadas de forma aleatória e após este primeiro contato tínhamos que romper barreiras para que nos respondessem a respeito de um vício que estávamos questionando. Explicávamos que era um trabalho de pesquisa da área odontológica com respaldo da D isciplina de Patologia e da Disciplina de O dontologia em Saúde Coletiva da FOB-USP, e que nenhum nome seria divulgado e não fazíamos nenhum tipo de comentário para não interferir nas respostas.

Alguns indivíduos falavam que não eram usuários, que nunca tinham usado até que os próprios colegas os convenciam a responder; este foi um fato bastante importante em todos os locais que fomos pois quando conversávamos com alguma pessoa que se interessava ou se propunha a ajudar, o próprio chamava os conhecidos usuários ou pessoas que sabiam ser.

Um ponto crítico da pesquisa foi a realização de exames intrabucais em ambientes não favoráveis, contando apenas com espátulas de madeira e iluminação natural ou artificial através de lanternas de uso comum. Dependendo do local a pessoa ficava em pé, o que provavelmente gerou a possibilidade de lesões incipientes importantes terem passado despercebidas. A colaboração do usuário durante o exame intrabucal não foi plena, pois estariam passando vergonha ou "pagando mico" diante das pessoas como mencionavam. 
Nossa intenção era examinar os usuários que apresentassem algum tipo de lesão na FO B-USP, mas muitos deram telefones errados ou não forneceram 0 número, outros eram de cidades da região ou não se interessaram. Nesses casos, somente após o total preenchimento do questionário dávamos orientações sobre os riscos do uso do TSF.

Baseados nos resultados obtidos, podemos afirmar que traçamos o perfil do usuário de TSF na região de Bauru. As características como gênero, faixa etária, grupo racial, formas e preferências de uso foram bem definidas. 0 usuário geralmente é do gênero masculino, sendo caracteristicamente adolescente com escolaridade média e, subjetivamente analisando-0, pertence à classe média. Apenas seis $(4,65 \%)$ dos usuários eram do gênero feminino como mostra a FIGURA 2. Estes dados podem ser corroborados por vários autores $3,14,16,33,44,46,62,80,82,86$. Distintamente, BROWN et al. ${ }^{10}$ e SUMMERS; WILLIAMS; CURZON ${ }^{77}$, em trabalhos realizados na Índia, relacionaram 0 vício do rapé entre mulheres de baixo rendimento e acreditavam que os lábios ficavam mais vermelhos e atraentes. $\mathrm{Na}$ China, YANG et al. ${ }^{87}$ e no Brasil, nossos resultados, revelaram o vício ser maior entre os homens; as mulheres consideram o uso grosseiro, causador de mau hálito, deixando os dentes sujos e os lábios avermelhados.

Provavelmente, o que leva os jovens brasileiros a usarem essa forma de tabaco é a imitação de um comportamento americano, pois os que não podem comprar o produto importado fazem uma mistura com o tabaco nacional de preço mais acessível. Este preparado será acondicionado em latas do produto importado, contribuindo para aumentar a auto-afirmação do adolescente, uma vez que essa fase de transição é de bastante insegurança para o jovem adolescente. Há uma busca para confirmar sua macheza ${ }^{18}$ e às vezes adota atitudes, hábitos ou vícios mais "brutalizados". Talvez seja esse o motivo do vício predominar no gênero 
masculino e ser aceito pelos pais, associando-se o fato do desconhecimento dos riscos deletérios à saúde.

Embora os jovens usuários prefiram o TSF importado, podemos relacionar o vício ao histórico "fumo de corda", característico de áreas rurais, pois toda nossa amostra foi encontrada em ambientes "country" e todos se referiam ao uso estimulado pelo ambiente. Quando perguntávamos se conheciam alguém que também usava o TSF, 100\% dos usuários relataram conhecer alguém relacionado a esse meio.

Não colhemos dados em outros tipos de ambientes como no meio esportista brasileiro entre jogadores de futebol, basquete e outros esportes. Isto nos leva sugerir outros trabalhos abrangendo um maior campo de ação ou trabalhos em outras populações específicas. Esta pesquisa de campo também assume um caráter exploratório para futuros trabalhos.

O TSF pode causar inúmeros e significantes efeitos nos tecidos bucais e estruturas dentárias: pigmentação dentária, alterações na coloração das restaurações estéticas, desgaste nas superfícies cervicais e incisais dos dentes com 0 uso excessivo como abrasão e erosão, recessão gengival, destruição periodontal, halitose, alteração no paladar, mudanças na coloração e espessamento da mucosa, leucoplasia e câncer bucal $33,19,33,41,43,48,64,66,70,80$.

As alterações clínicas mais comumente encontradas nos usuários de TSF em nosso estudo, foram: 19,37\% de recessões gengivais; 10,85\% de leucoplasias e 7,75\% de pigmentações dentárias como mostra a FIG URA 7.

As mudanças na cor dos dentes pelo uso do TSF são resultantes de interações físico-químicas entre a superfície dentária e os componentes do TSF. Uma vez dissolvidos na saliva, podem aderir à superfície do esmalte ou ainda por 
um mecanismo em que substâncias sem cor, reagem produzindo cromógenos após terem aderido à superfície dental, caracterizando 0 manchamento extrínseco ${ }^{61}$.

As alterações gengivais ocorrem em decorrência de agressões químicas e mecânicas que ocorrem na área onde o fumo é colocado. Nas áreas envolvidas, há liberação de mediadores inflamatórios, como a interleucina 1 e prostaglandina E2, inclusive pelas células epiteliais da mucosa bucal ${ }^{40}$. Assim, as recessões gengivais podem ser provocadas pelo tabaco como agente químico ou pelo ato mecânico de esfregar na gengiva e mesmo pela escovação mais vigorosa na tentativa de eliminar a pigmentação e halitose causadas pelo tabaco.

A faixa etária de maior prevalência do vício no uso do TSF foi dos 15 aos 19 anos, com percentual de 67,44\%, embora tenhamos encontrado usuários entre 10 e 30 anos (FIGURA 3). Tal característica no perfil do usuário pode ser também detectada em outros levantamentos epidemiológicos $16,17,37,41,43,62,64,72,80$.

Essa constatação leva à suposição de mudança no perfil do portador de leucoplasia bucal, a principal lesão cancerizável na mucosa bucal humana. Geralmente esta lesão cancerizável ocorre em pacientes de grupos etários maiores, acima dos 40 anos de idade, o mesmo ocorrendo em relação ao câncer bucal ${ }^{32}$. Com o vício do TSF predominando entre adolescentes, inclusive crianças, a faixa etária de maior comprometimento tende a ser em faixas de idades inferiores. 0 início precoce deste vício aumenta o contato e o tempo de exposição aos agentes carcinogênicos à medida que 0 indivíduo avança em idade.

A carcinogênese bucal representa a interação de inúmeros fatores, especialmente ambientais, atuando em períodos de tempo variáveis para formar um tumor maligno ${ }^{29}$. Os efeitos dos agentes carcinógenos ao longo do tempo têm efeito somatório. Neste processo há vários estádios de transformação e o tabaco 
reconhecidamente atua como um dos principais agentes carcinogênicos, aumentando consideravelmente os riscos do indivíduo aos cânceres de pulmão, laringe, cavidade bucal, faringe, esôfago, pâncreas e bexiga ${ }^{38,64,72,85}$.

A carcinogênese pode ser dividida em três fases: a iniciação, a promoção e a progressão ${ }^{28}$. Alguns agentes são primordialmente iniciadores, alterando as células, mas não levando-as à proliferação desordenada 0 que caracterizaria a neoplasia maligna instalada. Outros atuam apenas sobre células iniciadas por outros agentes, dando início morfológico à neoplasia, são os agentes promotores. Por fim, têm-se substâncias que apenas atuam promovendo o desenvolvimento de tumores já instalados.

O tabaco tem numerosas substâncias na sua composição química antes e após sua combustão. Sua ação múltipla acaba caracterizando-o como um carcinógeno completo; além de possuir a capacidade de lesar diretamente o DNA celular, aumenta a proliferação celular ${ }^{29}$. Quanto maior o tempo em que o TSF fica em contato com a mucosa bucal maior a lesão para área, podendo desenvolver uma leucoplasia no local.

O local de preferência para acomodação do TSF pelos usuários entrevistados foi o vestíbulo anterior inferior, com percentual de 79,84\%, quando se usa o rapé úmido; seguido pela mucosa jugal com $16,27 \%$ no caso do tabaco de mascar como visto na FIGURA 8. A predileção pelo vestíbulo anterior inferior bem como a freqüente associação com o aparecimento de leucoplasias nesta área foi constatada na revisão da literatura ${ }^{33,39,41,44,50,53,64,66,75,80,86}$ para outras regiões do mundo.

O câncer bucal representa a causa principal de doenças e mortes evitáveis $^{70}$. D etectando-se as condições pré-cancerosas ou estádios iniciais, a doença tem cura; essa prevenção quase não ocorre e segundo a Coordenação de Programas de Controle do Instituto Nacional do Câncer, alguns fatores contribuem para esta 
situação: difícil acesso da população aos serviços de assistência; despreparo dos profissionais de saúde quanto aos aspectos epidemiológicos e clínicos das lesões precursoras do câncer bucal e desarticulação entre as ações de prevenção, diagnóstico e tratamento ${ }^{29}$.

O vício do uso de TSF pode ser considerado um problema social; pois pode levar ao desenvolvimento de câncer bucal. Para SINAI ${ }^{71}$, um problema deve ser considerado de saúde pública quando:

- constitui causa comum de morbidade ou mortalidade;

- existem métodos eficazes de prevenção e controle;

- tais métodos não estão sendo utilizados de modo adequado pela comunidade.

A prevenção está diretamente associada a programas com finalidade educativa, preventiva e de intervenção, visando a diminuição do consumo do tabaco por parte da população mostrando claramente os seus efeitos maléficos. Essas campanhas devem ser implantadas em todos os seguimentos sociais e em todas as faixas etárias, principalmente em escolas de ensino fundamental buscando uma mudança de comportamento em relação aos já viciados ou desestimulando aqueles que ainda não têm 0 vício para que não 0 adquiram: a melhor prevenção ainda é não usar ${ }^{7,13,17,32,42,51,64,84,87}$.

Outro aspecto de importância fundamental está nas campanhas antitabagismo se reportarem aos perigos do cigarro como decorrente da fumaça, como: "apague essa idéia" ou "apague o cigarro antes que ele o apague", dando a falsa impressão do efeito deletério estar associado apenas à fumaça o que torna 0 TSF mais perigoso ainda pois alguns acreditam ser uma alternativa segura ao cigarro $^{16,19,31,50,51,54,62,64,72,75,93}$ o que pudemos confirmar em nossa pesquisa onde 104 ou $80,62 \%$ dos usuários de TSF, afirmaram que os pais sabiam sobre o uso do tabaco (FIG URA 13), ressaltando a falta de conhecimento sobre os efeitos 
deletérios do TSF, bem como da dependência química da nicotina caracterizada pelos sintomas da síndrome de abstinência ${ }^{16,37,50,51,62,64,77}$. No relato dos usuários, os pais apenas se referem ao vício como sendo algo "feio", "nojento", reforçando essa falta de conhecimento. Este fato também foi observado em outros estudos epidemiológicos realizados em outros países ${ }^{16,19,31}$. Não raro, pode-se ouvir: "Bem, pelo menos meu filho não fuma" ${ }^{75}$.

O grau de instrução dos usuários no presente estudo, em sua maioria está no nível médio, incluindo os da modalidade técnica profissionalizante, com percentual de 68,21\%, seguindo-se os de nível fundamental, com 25,58\% e, finalmente os que cursam o ensino superior com um percentual de 6,20\% (FIGURA 15). Uma observação chamou-nos atenção especial: um dos usuários tem nível universitário de ensino, cursa a graduação em Odontologia, e seu pai é cirurgião-dentista e professor universitário, salientando a falta de conhecimento sobre 0 assunto dos profissionais dessa área ${ }^{15}$. Há necessidade do desenvolvimento de programas visando os cirurgiões-dentistas e os futuros profissionais, papel este que deveria ser desenvolvido pelas Faculdades de O dontologia, contribuindo com a saúde pública e conseqüentemente qualidade de vida da população.

Mais da metade dos usuários entrevistados iniciaram o uso do TSF por meio da influência de amigos e usuários, assumindo um percentual de 58,91\%; já $37,20 \%$ alegaram que iniciaram este vício por mera curiosidade, enquanto que 3,87\% alegaram o "parar de fumar" como motivo para usar esse tipo de tabaco como substituto (FIGURA 16).

Em alguns casos, o uso dessa forma alternativa ao cigarro se dá por manter as mãos livres, não prejudicando as atividades da pessoa. D esta forma, algumas pessoas justificam ser usuários por não poderem fumar no local de 
trabalho ou escola. Também há alegações como "não faz tanto mal como o cigarro, não causa câncer de pulmão e ajuda passar o tempo, distrair e relaxar". Em outras situações nitidamente se reconhece o vício para promover auto-afirmação ou ainda para imitar alguém que se admira ${ }^{19,31,64,87}$.

Alguns estudos associam o uso do TSF a jovens com problemas comportamentais, usuários de bebida alcoólica, discriminação social, nível sócioeconômico baixo, analfabetismo ou pouca instruçã $0^{18,26}$. Neste trabalho, encontramos uma realidade oposta, a maioria dos entrevistados está cursando ou já concluiu o ensino médio, o nível sócio-econômico observado durante as entrevistas pode ser classificado como médio a alto; 0 TSF não é um produto barato e 0 consumo varia de uma lata a cada dois dias. Cada lata do produto custa em média quatro a cinco dólares americanos.

Poucos dados relatados relacionam o TSF à cárie dentária, apesar da presença de grande quantidade de glicose e sacarose na sua composição. O TSF pode ser considerado como agente cariogênico ${ }^{86}$, mas outros fatores devem ser considerados como atenuantes deste efeito: o aumento do fluxo salivar pelo contato com a mucosa bucal por algum tempo, o elevado conteúdo de bicarbonato na composição, o pH alcalino e 0 aumento da capacidade tampão. Uma ação protetora anticariogênica controversa está na adição de flúor; no tabaco de mascar há aproximadamente 2,01ppm, no rapé encontra-se 0,91ppm.

D evemos ressaltar a importância dos programas educativos-preventivos abrangendo todas as esferas políticas: municipais, estaduais e federais. 0 público alvo deve ser amplo, sem discriminação de faixa etária, gênero, nível sócioeconômico e grupo racial. A ação deve ter forma individual (clínica) e coletiva (saúde pública), abordando os quatro princípios de intervenção que devem nortear a ação dos cirurgiões-dentistas ${ }^{36}$ : 
1) Perguntar os hábitos em relação ao fumo

2) Aconselhar seu abandono

3) Auxiliar na execução do mesmo

4) Agendar consultas de acompanhamento.

Agindo assim, estaremos cumprindo nosso dever social como profissionais da saúde. Sugerimos o envolvimento das entidades odontológicas, das faculdades de odontologia e dos órgãos governamentais como Secretarias Municipais e Estaduais de Saúde e Ministério da Saúde na tomada de posição e consciência da sociedade para com o vício do uso do TSF pois representa um grave e insidioso problema social. 
7 CONCLUSÃO 


\section{CONCLUSÃO}

A partir dos resultados obtidos e considerando as limitações inerentes à metodologia de trabalho, podemos afirmar que o perfil do usuário de TSF na região de Bauru, Estado de São Paulo, se caracteriza por ser:

- adolescente,

- do gênero masculino,

- da raça branca,

- de escolaridade média,

- pertencente a classe média,

- de conhecimento dos pais à prática do vício,

- freqüentador de ambientes "country".

Os resultados permite-nos ainda concluir que há necessidade de providências no âmbito da saúde coletiva e da comunidade odontológica para tomada de posição e consciência da sociedade sobre os malefícios do vício do uso do TSF pois representa um grave e insidioso problema social. 
REFERÊNCIAS BIBLIOGRÁFICAS 


\section{REFERÊNCIAS BIBLIOGRÁFICAS*}

1 ANDERSON, G.; AXÉLL, T.; CURVALL, M. Reduction in nicotine intake and oral mucosal changes among users of Swedish oral moist snuff after switching to a low - nicotine product. J. oral Path. Med., v. 24, n. 6, p. 244-50, July 1995.

2 ANDERSON, G.; BJÖRNBERG, G.; CURVALL, M. Oral mucosal changes and nicotine disposition in users of Swedish smokeless tobacco products: a comparative study. J. oral Path. Med., v. 23, n. 4, p. 161 -7, Apr. 1994.

3 ANDREWS, J.A. et al. Relationship between tobacco use and self reported oral hygiene habits. J. Amer. dent. Ass., v. 129, n.3, p.313 -20, Mar. 1998.

4 AXÉL, H.; MÖRNSTAD, H.; SUNDSTRÖM, B. The relation of the clinical picture to the histophatology of snuff dipper's lesions in a Swedish population. J. oral Path. Med., v.5, p.229 - 36, 1976.

\footnotetext{
Normas recomendadas para uso no âmbito da Universidade de São Paulo, com base no documento "Orientações básicas para apresentação de dissertações e teses na FOB-USP", publicado pelo Serviço de Biblioteca e D ocumentação da Faculdade de O dontologia de Bauru Universidade de São Paulo, 1991.
} 
5 BABU,S.; SESIKERAN, B.;BHAT, R.V. O ral fibrosis among teenagers chewing tobacco, areca nut, and Pan malasa/ Letter/ . Lancet, v.348, n.7, p. 692, 1996.

6 BASTOS, J.R. de M; LOPES, E.S. Odontologia preventiva e social. Bauru, FOB-USP, 1988. p.179-87./ Apostila/

7 BENOWITZ, N.L. Systemic absorption and effects of nicotine from smokeless tobacco. Advanc. dent. Res., v.11, n.3, p.336-41, Sept. 1997.

8 BENSON, W. et al. Tobacco-use prevention and cessation: dentistry's role in promoting freedom from tobacco. J. Amer. dent. Ass., v.131, n.8, p. 1137- 43, Aug. 2000.

9 BOWLES, W.H. et al. Abrasive particles in tobacco products: a possible factor in dental attrition. J. Amer. dent. Ass., v.126, n.3, p.327-31, Mar. 1995.

10 BROWN, R.L. et al. Snuff dippers' intraoral cancer: clinical characteristic and response to therapy. Cancer, v.18, n.1, p.2-13, Jan. 1965.

11 BUCHER, R. Prevenindo contra as drogas e DST/ AIDS: populações em situação de risco. Ministério da Saúde. Programa Nacional de DST/ AID S. Brasília, out. 1995, 28 p. 
12 CAMPBELL, H.S. et al. Addressing oral disease- the case for tobacco cessation services. J. Canad. dent. Ass., v.67, n.3, p.141-5, Mar. 2001.

13 CAMPBELL, H.S.; SLETTEN, M.; PETTY, T. Patient perceptions of tobacco cessation services in dental offices. J. Amer. dent. Ass., v.130, n.2, p.219-26, Feb. 1999.

14 CD C. Tobacco use among high school students - United States, 1997. J. Amer. dent. Ass., v.279, n.16, p.1250 -1, Apr. 1998.

15 CHAIM, L. A. de F.; COPPI, L. C. Hábito de fumar e suas conseqüências nocivas aos tecidos bucais: avaliação do nível de conscientização de futuros profissionais de odontologia. Rev. ABO Nac., v.6, n.3, p.149 52, jun./ jul. 1998.

16 CHASE, R.H. Chewing tobacco and cancer: a growing threat. J. Mich. dent. Ass., v.79, n.2, p.38 - 40, Feb. 1997.

17 CHASE, R.H. Chewing tobacco and oral cancer: part two. J. Mich. dent. Ass., v.79, n.3, p.44-6, Mar. 1997.

18 CHEN, J.W.; SHAW, J.H. A study on betel quid chewing behavior among Kaohsiung residents aged 15 years and above. J. oral Path. Med., v.25, n.3, p. 140 -3, Mar. 1996. 
19 CHRISTEN, A.G. The case against smokeless tobacco: five facts for the health professional to consider. J. Amer. dent. Ass., v.101, n.3, p.4649, Sept. 1980.

20 CHRISTEN, A.G.; CHRISTEN, J.A. Smokeless tobacco: intervention techniques for the dental professional. Dent. Assist., v.65, n.5, p.9-17, Sept./ Oct. 1996.

21 CHRISTEN, A. G. et al. Smokeless tobacco: The folklore and social history of snuffing, sneezing, dipping, and chewing. J. Amer. dent. Ass., v.105, n.5, p.821-9, Nov. 1982.

22 CLARK, P.I. et al. Factors associated with tobacco sales to minors. J. Amer. med. Ass., v.284, n.6, p.729 -34, Aug. 2000.

23 DANIELS, T.E. et al. Histopathology of smokeless tobacco lesions in professional baseball players. Associations with different types of tabacco. Oral Surg., v.73, n.6, p.720-5, June 1992.

24 DANIELS, T.E. et al. Reduction of langerhans cells in smokeless tobacco associated oral lesions. J. oral Path. Med., v.21, n.3, p.100-4, Mar. 1992. 
25 DAUG HETY, V.S. et al. Surveying smokeless tobacco use, oral lesions and cessation among high school boys. J. Amer. dent. Ass., v.125, n.2, p.173-80, Feb. 1994.

26 DURANT, R.H. et al. The association of weapon carrying and fighting on school property and other health risk and problem behaviors among high school students. Arch. Pediat. Adolesc. Med., v. 151, n.4, p.360 6, Apr. 1997.

27 ERNSTER, V.L. et al. Smokeless tobacco use and health effects among baseball players. J. Amer. med. Ass., v.264, n.2, p.218-24, July 2000.

28 FASSO NI, A.A. Carcinogênese bucal química D MBA- induzida: estudo metodológico em hamsters sírios dourados. Bauru, 1992. 87p. Dissertação (Mestrado) - Faculdade de Odontologia de Bauru, Universidade de São Paulo.

29 GENOVESE, W.J.; BORDINI, P.J.; BORDINI, E.B.T. Câncer bucal. In: KIGNEL,S. Diagnóstico bucal. São Paulo, Robe, 1997. Cap.12, p.381422.

30 GOING, R.E. et al. Sugar and fluoride content of various forms of tobacco. J. Amer. dent. Ass., v.100, n.1, p.27-33, Jan. 1980. 
31 GREEN, T. Breaking the link between snuff and athletas. Pennsylvania dent. J., v.62, n.2, p.13-9, Mar./ Apr. 1995.

32 GREENE, J.C.; WALSH, M.M.; MASOUREDIS, C. A program to help major league baseball players quit using spit tobacco. J. Amer. dent. Ass., v.125, n.5, p.559-68, May 1994.

33 GREER JUNIOR, R.O.; POULSON, T.C. Oral tissue alterations associated with the use of smokeless tobacco by teen - agers, Oral Surg., v.56, n.3, p.275-84, Sept. 1983.

34 GREGORY, R.L. et al. Effect of smokeless tobacco use in humans on mucosal immune factors. Arch. Pediat. Adolesc. Med., v.36, n.1, p.25-31, 1991.

35 HASSÉUS, B. et al. Immunotoxic effects of smokeless tobacco on the acessory cell function of rat oral epithelium. Europ. J. oral Sci, v.105, n.1, p.45 -51, Feb. 1997.

36 HATSUKAMI, D.K.; BOYLE, R.G. Prevention and treatment of smokeless tobacco use. Advanc. dent. Res., v.11, n.3, p. 342-9, Sept. 1997. 
37 HENNING FIELD, J.E.; FANT, R.V.; TOMAR, S.L. Smokeless tobacco: na addicting drug. Advanc. dent. Res., v.11, n.3, p.330-5, Sept. 1997.

38 HOFFMANN, D.;DJORDJEVIC, M.V. Chemical composition and carcinogenicity of smokeless tobacco. Advanc. dent. Res., v.11, n.3, p.322-9, Sept. 1997.

39 ID RIS, A.M. et al. Toombak- associated oral mucosal lesions in Sudanese show a low prevalence of epithelial dysplasia. J. oral Path. Med., v. 25, n. 5, p. 239-44, May 1996.

40 JOHNSON, G.K. et al. Effect of smokeless tobacco extract on human gingival keratinocyte levels of prostaglandin E2 and interleukin-1. J. Periodont., v.67, n.2, p.116 -24, Feb. 1996.

41 JOHNSON, G.K.; SQUIER, C.A. Smokeless tobacco use by youth: a health concern. Pediat. Dent., v.15, n.3, p.169-74, May/ June 1993.

42 JO NES, R.B. Tobacco or oral health: past progress, impending challenge. J. Amer. dent. Ass., v.131, n.8, p. 1130-36, Aug. 2000.

43 KAUGARS, G.E. et al. Evaluation of risk factors in smokeless tobacco associated oral lesions. Oral Surg., v.72, n.3, p.326 -31, Sept. 1991. 
44 KAUGARS, G.E. et al. The prevalence of oral lesions in smokeless tobacco users and an evaluation of risk factors. Cancer, v.70, n.11, p.2579 -85, Dec. 1992.

45 KESSLER, D.A. et al. The legal and scientific basis for FDA's assertion of jurisdiction over cigarettes and smokeless tobacco. J. Amer. med. Ass., v.5, n.5, p.405-9, Feb. 1997.

46 KLEINMAN, D.V.; SWANGO, P.A.; PINDBORG, J.J. Epidemiology of oral mucosal in United States schoolchildren: 1986 - 87. Community Dent. oral E pidem., v.22, n.4, p.243-53, Aug. 1994.

47 LEITE,A. O tabagismo e a boca. Rev. Ass. paul. cinurg. Dent., v.55, n.1, p.7-14, jan./ fev. 2001.

48 LEONEL, F.; TOMITA, N.E. O fumo e a doença periodontal. Rev. ABO Nac., v.7, n.5, p.294-7, out./ nov. 1999.

49 LINK, M.J.O.; KAUGARS, G.E.; BURNS,A.J.C. Comparison of oral carcinomas in smokeless tobacco users and nonusers. J. oral Maxillofac. Surg., v.50, n.5, p.452-5, May 1992. 
50 LITTLE, S.J. et al. Effective smokeless tobacco intervention for dental hygiene patients. J. dent. Hyg., v.66, n.4, p.185-90, May 1992.

51 LITTLE, S.J. et al. Smokeless tobacco and oral mucosal lesions in dental patients. J. Publ. Hlth. Dent., v.52, n.5, p.269-76, 1992.

52 MAILTO , A. Que outro jeito existe em que se possa viciar-se em nicotina? Disponível na Internet: http:/ / A:l Capítulo16.htm. 5/ 12/ 2000.

53 MARTIN, G.C. et al. O ral leukoplakia status six weeks after cessation of smokeless tobacco use. J. Amer. dent. Ass., v.130, n.7, p.945-54, July 1999.

54 MASOUREDIS, C.M. et al. A spit tobacco cessation intervention for college athletes: three - month results. Advanc. dent. Res., v.11, n.3, p.354-9, Sept. 1997.

55 McCANN, D. Surgeon general warns against use of smokeless tobacco. J. Amer. dent. Ass., v.124, n.2, p.22, Feb. 1993.

56 MERAW, S.J.; MUSTAPHA, I.Z.; ROGERS, R.R. Cigarette smoking and oral lesions other than cancer. Clin. Dermatol., v.16, n.5, p.625 -31, Sept./ Oct. 1998. 
57 MINISTÉRIO DA SAÚDE INSTITUTO NACIONAL DE CÂNCER. CONTAPP - COORDENAÇÃO NACIONAL DE CONTROLE DO TABAGISMO E PREVENÇÃO PRIMÁRIA DE CÂNCER. A História do Tabaco. Disponível na Internet: http:// A:\A História do tabaco.htm. 5/ 12/ 2000.

58 MINISTÉRIO DA SAÚDE INSTITUTO NACIONAL DE CÂNCER. CONTAPP - COORDENAÇÃO NACIONAL DE CONTROLE DO TABAGISMO E PREVENÇÃO PRIMÁRIA DE CÂNCER. Tabaco. Disponível na Internet: http:/ / A:l tabaco.htm. 5/ 12/ 2000.

59 MIRBOD, S.M.; AHING, S.I. Tobacco-associated lesions of the oral cavity: part I. Malignant lesions. J. Canad. dent. Ass., v.66, n.5, p.2526, May 2000.

60 MIRBOD, S.M.; AHING, S.I. Tobacco-associated lesions of the oral cavity: part II. Malignant lesions. J. Canad. dent. Ass., v.66, n.6, p.30812, June 2000.

61 NATHOO, S.A. The chemistry and machanisms of extrinsic and intrinsic discoloration. J. Amer. dent. Ass., v.128 (suppl), p.6S-10S, Apr. 1997.

62 PROKHOROV, A.V. et al. Spit tobacco intervention in dental practice: recommendations for clinicians. Tex. dent. J., v.115, n.6, p.59-63, June 1998. 
63 RIGOTTI, N.A.; LEE, J.E.; WECHSLER, H. US college students' use of tobacco products. J. Amer. med. Ass., v.284, n.6, p.699 -705, Aug. 2000.

64 RINCHUSE, D.J. Dental implications of smokeless tobacco use. Pennsylvania dent. J., v.62, n.2, p.33-6, Mar./ Apr. 1995.

65 ROBERTSON, P.B. et al. Smokeless tobacco use: how it affects the performance of major league baseball players. J. Amer. dent. Ass., v. 126, n. 8, p.1115-21, Aug. 1995.

66 ROBERTSON, P.B.; WALSH, M.M.; GREENE, J.C. Oral effects of smokeless tobacco use by professional baseball players. Advanc. dent. Res., v.13, n.3, p. 307-12, Sept. 1997.

67 ROUTH, H.B. et al. Historical aspects of tobacco use and smoking. Clin. Dermatol., v.16, n.5, p.539-44, Sept./ Oct. 1998.

68 SAMEK, L. Tobacco cessation: isn't it time for dentistry to become more involved. J. Canad. dent. Ass., v.67, n.3, p.139-40, Mar. 2001.

69 SAND HU, H.S. A practical guide to tobacco cessation in dental offices. J. Canad. dent. Ass., v.67, n.3, p.153-7, Mar. 2001. 
70 SEVERSON, H.H. Tobacco cessation in the dental office: a brief intervention for spit tobacco users. Q uintessence Int., v.29, n.4, p. 2625, Apr. 1998.

71 SINAI,N. Problemas. In: CHAVES, M.M. Odontologia Social. 3.ed. Artes Médicas, 1986. Cap. 2, p. 23-98.

72 SPEER, J.A. Smokeless tobacco: a student craze. Dent. Assist., v.59, n.5, p.9-11, Sept./ Oct. 1990.

73 STATEMENT, J. Tobacco: the role of health professionals in smoking cessation. J. Canad. dent. Ass., v.67, n.3, p.134-5, Mar. 2001.

74 STEVENS,V.J. et al. Making the most of a teachable moment: a smokeless tobacco cessation intervention in the dental office. Amer. J. publ. Hlth., v. 85, n.2, p. 231-5, Feb. 1995.

75 STRAFFON, D.; McGOWAN, J.M. Spit tobacco: not a safe alternative. J. Mich. dent. Ass., v.79, n.4, p.28-31, Apr./ May 1997. 
76 SUMMERLIN,D.J.; DUNIPACE,A.; POTTER,R. Histologic effect of smokeless tobacco and alcohol on the pouch mucosa and organs of the Syrian hamster. J. oral Path. Med., v.21, n.3 , p.105-8, Mar. 1992.

77 SUMMERS, R.M.; WILLIAMS, S.A.; CURZON, M.E.J. The use of tobacco and betel quid ("pan") among Bangladeshi woman in West Yorkshire. Community dent. Hlth., v.11, n.1, p.12-6, Mar. 1994.

78 TILASHALSKI, K.; RODU, B.; MAYFIELD, C. Assessing the nicotine content of smokeless tobacco products. J. Amer. dent. Ass., v.125, n.5, p.590-2, May 1994.

79 TOMAR, S.L. et al. Do dentist and physicians advise tobacco users to quid? J. Amer. dent. Ass., v.127, n.2, p.259-65, Feb. 1996.

80 TOMAR, S.L. et al. Oral mucosal smokeless tobacco lesions among adolescents in the United States. J. dent. Res., v.76, n.6, p.1277-86, June 1997.

81 TOMAR, S.L.; GIOVINO, G.A.; ERIKSEN, M. P. Smokeless tobacco brand preference and brand switching among US adolescents and young adults. Tobacco control, v.4, p.67-72, 1995.

82 TOMAR, S.L.; WINN, D.M. Chewing tobacco use and dental caries among U.S. J. Amer. dent. Ass., v.130, n.11, p.1601-10, Nov. 1999. 
83 WALSH, M.M. et al. A dental - based, athletic trainer- mediated spit tobacco cessation program for professional baseball players. CDA, v.26, n.5, p. 365-7, May 1998.

84 WALSH, M.M. et al. Smokeless tobacco cessation intervention for college athletes: results after 1 year. Amer. J. publ. Hlth., v.89, n.2, p.228-34, Feb. 1999.

85 WINN, D.M. Epidemiology of cancer and other systemic effects associated with the use of smokeless tobacco. Advanc. dent. Res., v.11, n.3, p.313-21, Sept. 1997.

86 WRAY, A.; McGrirt, W.F. Smokeless tobacco usage associated with oral carcinoma. Incidence, treatment, outcome. Arch. Otolaryng. head neck Surg., v.119, n.9, p.929-33, Sept. 1993.

$87 \quad$ YANG , M.S. et al. Prevalence and related risk factors of betel quid chewing by adolescent students in southern Taiwan. J. oral Path. Med., I n.2, p.69-71, Feb. 1996.

88 ZAIN, R.B. et al. Oral mucosal lesions associated with betel quid, areca nut and tobacco chewing habits: consensus from a workshop held in Kuala Lumpur, Malaysia, November 25 - 27, 1996. J. oral Path. Med., v.28, n.1, p.1-4, Jan. 1999. 
ABST RACT 


\section{ABST RACT \\ The user's of smokeless tobacco profile}

Analyzing the smoking habits, it is noticed the decline in the use of cigarette for the popular campaigns on the malefaction caused by the bad habit of smoking. However, it has been resurged a millenary bad habit used in rituals and habits of the American indigenous societies and, also practiced by Egyptians, Persians and Chinese since the year 1000 B.C.: the use of the smokeless tobacco (TSF). This bad habit is usually used in several forms as aspired, applied on the mucous and chewed, it appeared as idiom or substitute of the cigarette. The people believe to be a safe alternative to the cigarette induced by a creative marketing, conditioning the TSF in cans that remind candies and with a good looking, mainly for young. The methodology to determine the user's of TSF profile was application of interviews aided by a questionnaire specifically elaborated with youths and adult visitors of typical atmospheres of country culture, as the rodeos parties, classes of equine trainings and championships of these modalities in the area of Bauru. The user of TSF in the area of Bauru, State of São Paulo, was characterized by been: adolescent, masculine gender, white race, medium schooling, from the middle class, their parents knowledge the practice of their bad habit and visitor og the country ambient.

The results show us to end that, there is necessary some providences in the collective health and the dentist's community for position taking and conscien the society on the malefactions with the use of TSF, because it represents a serious and insidious social problem. 
APÊNDICE 
Para: $\mathrm{S} r^{\mathrm{a}}$. Neusa

Gabinete DIR-X - Secretaria de Estados da Saúde de Bauru

Fax: (14) 234-8166

Prezada Sra

Com relação às questões que nos foram encaminhadas, esclarecemos que:

(1) Encontra-se em vigor a resolução da Agência Nacional de Vigllância Sanitária, BDC n0105 de 31 de male de 2001 a qual determina que todas as empresas fabricantes nacionais, importadoras ou exportadoras de produtos derivados de tabaco, incluindo fumo mascável, devem encaminhar solicitaçăo de cadastro (registro) para cada marca de produto (nome comercial) de forma individualizada, à Age̊ncia Nacional de Vlgilåncia Sanitária.

Essa resolução está disponivel na página da Agência, http: //www.anvisa.gox.hr. na área de atuação Derivados do Tabaco.

(2) Os produtos são apenas cadastrados na ANVISA/MS. A ANVISA em conjunto com o Instituto Nacional de Câncer - INCA/MS está implantado um Laboratórlo Oficial que realizará as análises desses produtos.

(3) ExIste a Lei 8069/90, que Institui o Estatuto da Criança e do Adolescente, no seu art. 81, inciso III, disciplina que é proibida a venda à criança ou ao adolescente de produtos cujos componentes possam causar dependênela físıca ou psíquica, prevendo no seu art. 243, as penalidades a serem aplicadas no caso de descumprimento. 
(4) Tanto a ANVISA quanto o INCA possuem sites disponivels para consulta: www,anvisacovebr e wwwinca.orgabr

(5) A Coordenação de Prevenção e Vigllância do Câncer do Instltuto Nacional te Câncer - CONPREV/INCA/MS possul alguns artigos a respeito. Porém mals informações podem ser encontradas nos seguintes sites: www.topaccolnstitute.com, umw.tobaçcopedia.org, wmw.golbalink.opg .

(6) Oprojeto de Lei $n^{0} 3156$ foi discutido e votado no Congresso Nacional e tornouse lei em 27 de dezembro de 2000, publicada como a Lei no10.167. Essa le pode ser encontrada tanto no site da ANVISA quanto no site do INCA.

Atenciosamente,

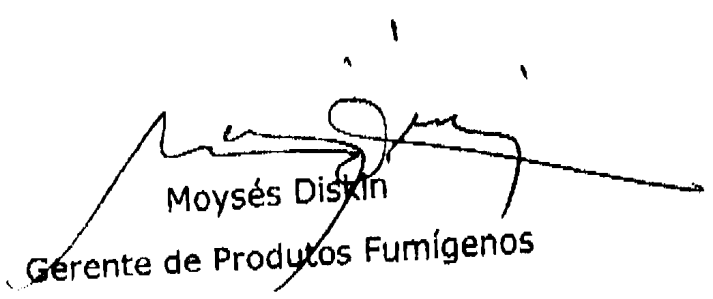

Agência Nacional de Vigllância Sanitária - ANVISA/MS

Diretoria de Alimentos e Toxicologia SEPN, 515, Bloco "B", Ed. Ômega, 30 andar. Brasília - DF

CEP: $70.770-502$ 